\title{
Beyond vessels: occurrence and regional clustering of vascular endothelial (VE-)cadherin-containing junctions in non-endothelial cells
}

\author{
Judit Boda-Heggemann • Anne Régnier-Vigouroux • \\ Werner W. Franke
}

Received: 25 September 2008 / Accepted: 2 October 2008 / Published online: 11 November 2008

(C) The Author(s) 2008. This article is published with open access at Springerlink.com

\begin{abstract}
The genes encoding transmembrane glycoproteins of the cadherin family, i.e., the $\mathrm{Ca}^{2+}$-dependent cell-cell adhesion molecules, are typically expressed in cell-type- or cell-lineage-specific patterns. One of them, vascular endothelial (VE)-cadherin, is widely considered to be specific for vascular endothelia in which it is either the sole or the predominant cadherin, often co-existing with $\mathrm{N}$-cadherin. This specificity of VE-cadherin for vascular endothelial cells is important not only in blood and lymph vessel biology and medicine, but also for cell-type-based diagnoses, notably those of metastatic tumors. Surprisingly, however, we have recently noted the frequent synthesis, surface exposure, and junction assembly of VE-cadherin in certain other cells, in which this glycoprotein is clustered into adherens junctions (AJs), either alone or in combination with $\mathrm{N}$-cadherin and/or cadherin-11. Such cells include mammalian astrocytes and
\end{abstract}

This work was supported in part by the Deutsche Krebshilfe (grant 10 2049 Fr1) and the German Ministry for Research and Technology (Program Regenerative Medicine, START-MSC consortium).

J. Boda-Heggemann · W. W. Franke $(\bowtie)$

Helmholtz Group for Cell Biology,

German Cancer Research Center (DKFZ),

Im Neuenheimer Feld 581,

69120 Heidelberg, Germany

e-mail: w.franke@dkfz.de

A. Régnier-Vigouroux

Division of Tumor Virology,

German Cancer Research Center (DKFZ)-INSERM U701,

Im Neuenheimer Feld 242,

69120 Heidelberg, Germany

Present address:

J. Boda-Heggemann

Department of Radiation Oncology, Mannheim Medical Center,

University of Heidelberg at Mannheim,

Mannheim, Germany glioma, probably mostly astrocytoma cells growing in culture, and a specific subtype of astrocytoma in situ. Moreover, VE-cadherin synthesis and AJ assembly, plus the regional clustering of such AJs in certain domains, are not clonally fixed but can appear again and again in cells of the progeny of cloned homogeneous-appearing individual cells, thus resulting in clonal cell colonies that are often heterogeneous in their cadherin junction patterns. We discuss the constitutive presence of VE-cadherin in some nonendothelial cells with respect to certain architectural features and possible physiological and pathogenic functions of the cells, and in comparison with recent reports of VE-cadherinpositive melanomas.

Keywords Endothelial cells · Glial cells · Astrocytes · Gliomas $\cdot$ Melanoma cells $\cdot$ VE-cadherin

\section{Introduction}

Cell-cell interactions of vertebrates, in particular cell-cell adhesions and tissue formations, are mediated and architecturally organized by intercellular junctions in many systems. These include, other than the tight and the gap junctions, the diverse types of adhering junctions that are usually subdivided into the desmosomes (maculae adhaerentes) and the adhaerens junctions (AJs), which, according to their specific morphological arrangement and molecular composition, can be divided into more extended zonulae or fasciae adhaerentes and the small and mostly nearisodiametric puncta adhaerentia. The desmosomes with their characteristic desmosomal cadherins of the desmoglein (Dsg1-4) and desmocollin (Dsc1-3) group and their associated cytoplasmic plaque proteins, i.e., desmoplakin, plakoglobin, and one or two plakophilins of the PKP1-3 
subfamily of so-called armadillo-type proteins, are typical of epithelial and epithelium-derived cells, including carcinomas, although desmosome protein ensembles also occur in junctions connecting meningeal and myocardial cells and in certain reticulum cell systems, in particular those of the thymus and the lymph nodes (e.g., Farquhar and Palade 1963; Staehelin 1974; Franke et al. 1982; Schwarz et al. 1990; Garrod et al. 2002; Godsel et al. 2004). On the other hand, AJs contain, in addition to their subtype-specific complement of AJ cadherins, a complex but characteristic ensemble of cytoplasmic plaque proteins formed by members of the group of $\alpha$ - and $\beta$-catenin, together with proteins p0071, ARVCF, and neurojungin, plus plakoglobin, which so far is the only protein common to both kinds of junctions (for definitions and references see, e.g., Cowin et al. 1986; Franke et al. 1989; Peifer and Wieschaus 1990; Peifer et al. 1992; Perez and Nelson 2004; Hatzfeld 2007). Right from the discovery of cadherins as major junctional molecules, the various members of this glycoprotein family have been noted to be synthesized and assembled into junctions in combinations and with AJ patterns characteristic of the specific cell type (e.g., Takeichi 1977, 1990, 1995; Behrens et al. 1985; Vestweber and Kemler 1985; Hatta and Takeichi 1986; Nagafuchi and Takeichi 1989; Ozawa and Kemler 1990; Steinberg and Takeichi 1994; Gumbiner 1996; Steinberg 1996; Steinberg and McNutt 1999; Redies 2000; Angst et al. 2001; Garrod et al. 2002; Wheelock and Johnson 2003).

Changes of the cadherin type or at least of the ratio of the cadherins present in a certain kind of AJ have also been reported in numerous studies. In particular, the process of "cadherin switching" has attracted special attention, most of all in the form of reports that, for example, in epithelial cells, a switch from E- to N-cadherin is associated with malignant cell transformation, notably metastasis (e.g., Behrens et al. 1993; Miettinen et al. 1994; Miyaki et al. 1995; Hazan et al. 1997, 2000; for a comprehensive review see Strumane et al. 2004).

Endothelial cells of blood and lymph vessels are characterized by zonula-adhaerens-like junctions based on a special vascular endothelial (VE)-cadherin, which often coexists with $\mathrm{N}$-cadherin (in some cell systems, also with cadherin11 ), but the question of the colocalization of VE- and Ncadherin is still intensely debated (e.g., Salomon et al. 1992; Lampugnani et al. 1995; Dejana 1996; Lampugnani and Dejana 1997; Navarro et al. 1998; Luo and Radice 2005). The glycoprotein, VE-cadherin, is certainly important in endothelial cell-cell adhesion and the formation of a good endothelial barrier and is regarded as an endothelial hallmark component serving a general and important function, i.e., the sealing of a vascular lumen on the one hand and a regulated passage control on the other (e.g., Caveda et al. 1996; Carmeliet et al. 1999; Dejana et al. 1999; Dejana 2004; see therein for further references). It has also been seen as an endothelium-specific molecule strictly associated with angiogenesis. Therefore, we and others have been surprised to note that VE-cadherin can also occur in certain other normal and malignantly transformed cell types, "anti-dogmatic" observations that, however, are so clear and consistent that we want to share them with the biological and medical community.

\section{Materials and methods}

\section{Cell cultures and cell culture lines}

The following cell cultures and cell culture lines were grown, usually with passage intervals of 3 or 4 days, as

Table 1 Proteins and glycoproteins demonstrated in immunoprecipitates with given antibodies to the specific cadherin by subsequent SDSpolyacrylamide gel electrophoresis and immunoblotting $(+$ positive

\begin{tabular}{llll}
\hline $\begin{array}{l}\text { Protein or glycoprotein } \\
\text { identified }\end{array}$ & $\begin{array}{l}\text { Immunoprecipitate with N- } \\
\text { cadherin }\end{array}$ & $\begin{array}{l}\text { Immunoprecipitate with VE- } \\
\text { cadherin }\end{array}$ & $\begin{array}{l}\text { Immunoprecipitate with cadherin- } \\
11\end{array}$ \\
\hline N-Cadherin & + & - & - \\
VE-Cadherin & - & + & - \\
Cadherin-11 & -+ & - & + \\
$\beta$-Catenin & + & + & + \\
$\alpha$-Catenin & + & + & + \\
Plakoglobin & + & - & + \\
Protein p120 & + & + & - \\
Protein ARVCF & + & + & - \\
Plakophilin-2 & + & + & - \\
Cingulin & + & + & - \\
Protein ZO-1 & - & + & n.d. \\
Afadin & - & n.d. & + \\
Protein p0071 & + & & \\
\hline
\end{tabular}

immunoblot result, - negative immunoblot result, -+ inconsistent results in different experiments, $n . d$. not determined) 


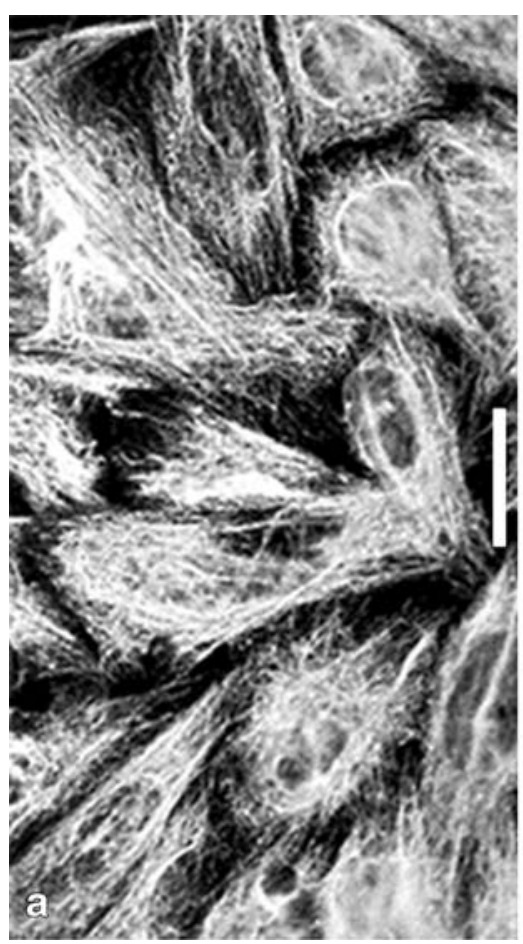

Fig. 1 Immunofluorescence microscopy presenting three major cytoskeletal and junctional proteins of glioma cells in culture, here of the human line U333/MG, i.e., cytoplasmic bundles of intermedi-

detailed elsewhere (Achtstätter et al. 1986; Boda-Heggemann 2005). If not stated otherwise, the studied human cell lines were obtained from gliomas, in most cases probably of astrocytoma origin, including cases of defined glioblastoma multiforme origin (in the terminology and characterizations of the cells and tumors mentioned, we essentially follow the work of Kleihues and Cavenee 2000): U333/MG, U87MG, U138MG, U373MG, T98G (for origins, differentiation markers, and relevant references, see Pontén and Macintyre 1968; Stein 1979; Osborn et al. 1981; Achtstätter et al. 1986; de Ridder et al. 1987; Boda-Heggemann 2005). In addition, we used cultures of cells specifically derived from a glioblastoma multiforme (a kind gift from György Vereb, University of Debrecen, Hungary). For comparison, we also employed the following established human and murine cell lines (from ATCC, Manassas, Va., USA): CaCo-2 and HT29 (from colon adenocarcinomas), MCF-7 (from breast carcinoma), PLC, SkHep, and HepG2 (from hepatocellular carcinomas), A431 (from squamous cell carcinomas of the vulva) and A431-A1B2 cells, a A431 subline stably transfected to express neurojungin (Paffenholz and Franke 1997; Paffenholz et al. 1999), and "SV80 fibroblastoidal cells", transformed by the SV40-large T-component. In addition, we studied non-malignant, permanently growing human keratinocytes of line HaCaT (Boukamp et al. 1988). As primary and secondary human endothelial cell cultures, we examined human umbilical cord endothelial cells of the line ate-sized filaments containing vimentin (a), glial filament protein (GFAP, b), and N-cadherin (c). Bars $20 \mu \mathrm{m}$

HUVEC (cf. Peitsch et al. 1999) and human mesenchymal stem cells (MSC), i.e., cells obtained from bone marrow and grown in culture (cf. Wuchter et al. 2007).

As endothelial cell cultures of animal origin, we routinely used bovine CPAE cells for comparison (Ryan

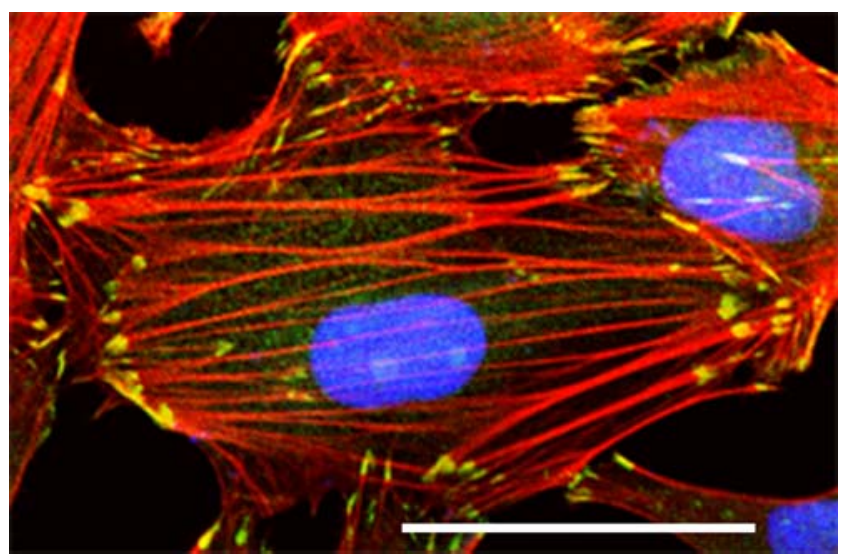

Fig. 2 Immunofluorescence microscopy of U333/MG glioma cells in culture showing the abundance of actin microfilament bundles, stained here with phalloidin coupled to the dye Alexa-594 (red), which anchor at the plaques of focal adhesions, visualized by immunostaining with antibodies against vinculin (green), resulting in a yellow-orange merge color. For comparison, nuclei have been stained with DAPI (Hoechst dye; blue). Bar $20 \mu \mathrm{m}$ 


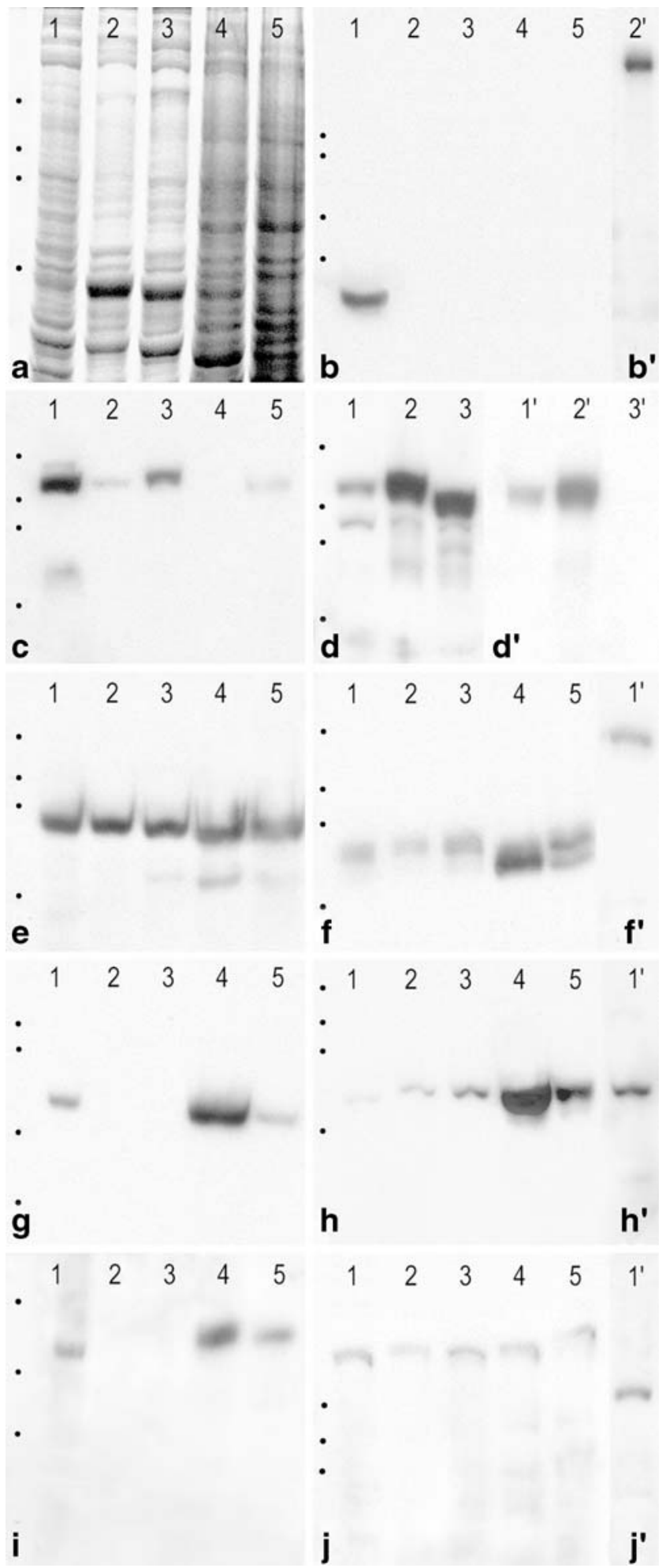

et al. 1978; Franke et al. 1979). Murine primary cell cultures of astrocytes prepared from brains of newborn mice (cf. Burudi et al. 1999; for details, see also BodaHeggemann 2005) were as described elsewhere (Burudi et al. 1999; Gresser et al. 2001).
Fig. 3 Biochemical identification and characterization of intercellular adhering junction (AJ) proteins as revealed by SDS-polyacrylamide gel electrophoresis (SDS-PAGE) and immunoblotting with specific antibodies (for further details see Boda-Heggemann 2005). The lanes contain total proteins of cell lysates (a, lane 1 U333/MG cells [Coomassie blue staining], lane 2 human umbilical cord endothelial cells grown in culture, lane 3 calf lens endothelial cells of line CPAE, lane 4 colon carcinoma cells of line $\mathrm{CaCo}-2$, lane 5 hepatocytic tumor cells of line PLC. The SDS-PAGE-separated proteins shown in a were reacted with antibodies against GFAP $(\mathbf{b})$, endothelial factor VIII ( $\mathbf{b}^{\prime}$, only lane 2 is shown here), N-cadherin (c), VE-cadherin $\left(\mathbf{d}, \mathbf{d}^{\prime}\right), \beta$ catenin (e), protein p120 (f), neurojungin (f'), plakophilin-2 (g), plakoglobin (h), plakoglobin after longer exposure (h'), cingulin (i), protein ZO-1 (j), and protein ZO-2 (j'). These reactions show that the U333 glioma cells (lane 1) contain N-cadherin but also VE-cadherin $\left(\mathbf{d}, \mathbf{d}^{\prime}\right), \beta$-catenin (e), protein p120 (f), plakophilin-2 (g), plakoglobin (minor amounts, only faintly visible after prolonged exposure, $\mathbf{h}^{\prime}$, lane $\left.1^{\prime}\right)$, cingulin (i) and proteins $\mathrm{ZO}-1$ and $\mathrm{ZO}-2\left(\mathbf{j}, \mathbf{j}^{\prime}\right)$. Positions of molecular weight markers are indicated left (from top): 158, 116, 97, and $66.4 \mathrm{kDa}$

The cloning of individual cells and establishment of subclone cell cultures were essentially as described for diverse other cell cultures (Knapp and Franke 1989; Knapp et al. 1989).

\section{Tissue samples}

Tissue samples of human brain and of human brain tumor, taken in accord with the specific local clinical regulations, were obtained from Dr. G. Csécsei and Dr. Àlmos Klekner (Institute of Neurosurgery, University of Debrecen, Hungary), Dr. Zoltán Nemes (Institut of Pathology, University of Debrecen, Hungary), and Markku Miettinen (Armed Forces Institute of Pathology, Washington, D.C., USA). Bovine and rodent tissue samples were obtained from freshly killed animals. The tissue sample pieces were frozen or fixed and processed as described elsewhere (Moll et al.

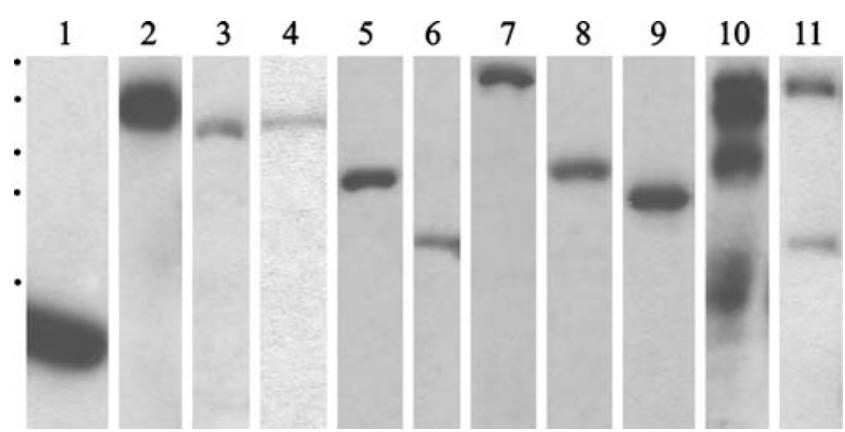

Fig. 4 SDS-PAGE-immunoblot reactions of total proteins from murine astrocytes grown in primary cultures. Reactions shown were obtained with antibodies against GFAP (lane 1), N-cadherin (lane 2), VE-cadherin (lane 3), cadherin-11 (lane 4), plakophilin-2 (lane 5), plakoglobin (lane 6), protein ZO-1 (lane 7), $\alpha$-catenin (lane 8), $\beta$ catenin (lane 9), ponsin (lane 10), and afadin (lane 11). Positions of molecular weight markers co-electrophoresed are indicated left (from top): $212,158,116,97$, and $66.4 \mathrm{kDa}$. In lanes 10 and 11 , the specific uppermost bands represent the intact polypeptide 


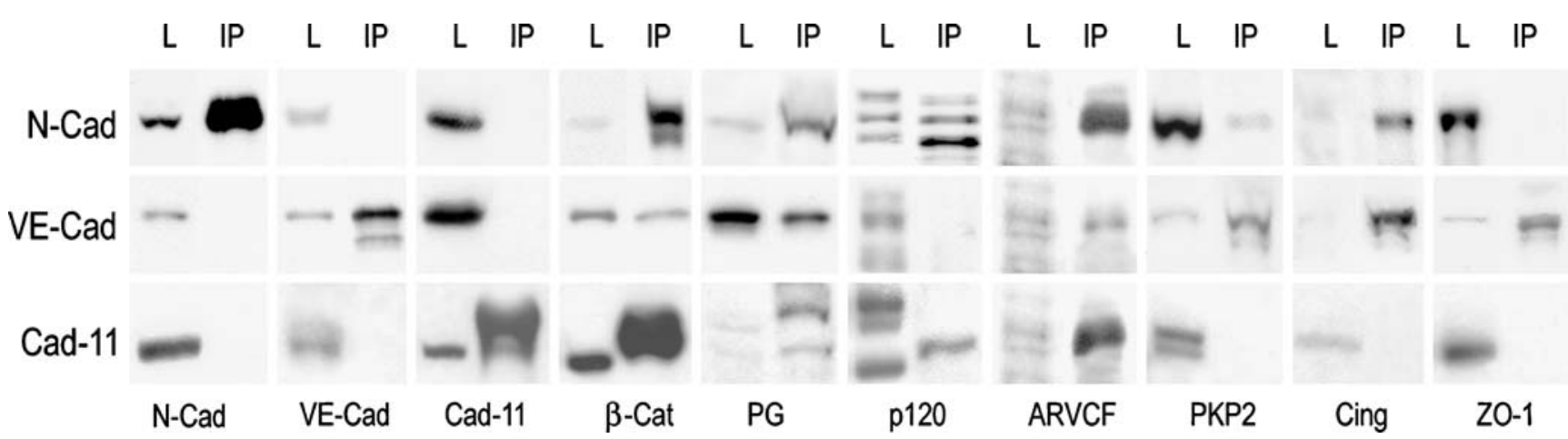

Fig. 5 Biochemical demonstration of cadherin-containing complexes in immunoprecipitates from total protein lysates of glioma U333 cells (IP buffer A containing $1 \%$ Triton $\mathrm{X}-100$ and $0.5 \mathrm{mM} \mathrm{CaCl} 2$ ), analyzed by SDS-PAGE and immunoblotting. Top Immunoprecipitates obtained with antibodies against $\mathrm{N}$-cadherin. Middle Immunoprecipitates obtained with VE-cadherin antibodies. Bottom Reaction products of complexes obtained with cadherin-11 antibodies. For each reaction, the total lysate $(L)$ is compared with the specific immunoprecipitate $(I P)$. The antibodies used for immunoblotting are indicated below. Note that N-cadherin antibodies here have co-immunoprecipi-

2008; Boda-Heggemann 2005; Hämmerling et al. 2006; Langbein et al. 2002, 2003).

Antibodies and immunolocalization protocols

In addition to the antibodies listed as Supplementary Material in Table 1 of the accompanying article by Moll et al. (2008), the following antibodies were used:murine monoclonal antibodies (mAbs) to VE-cadherin (BV9; kind gift of E. Dejana, University of Milano, Italy; and ab 7047, from Abcam, Cambridge, U.K.); R-cadherin (BD Biosciences, San Jose, Calif., USA); M-Cadherin (Research Diagnostics, Flanders, N.J., USA); cadherin-6 (US Biologicals, Swampscott, Mass., USA); neurojungin (Progen Biotechnik, Heidelberg, Germany; Paffenholz et al. 1999); vimentin (Progen Biotechnik; Franke et al. 1978; Herrmann et al. 1989); glial fibrillary protein (GFAP; Roche Diagnostics, Mannheim, Germany); nestin (Santa Cruz Biotechnolgy, Santa Cruz, Calif., USA); desmin (Dako, Hamburg, Germany); pancytokeratin (Dianova, Hamburg, Germany; cf. Franke et al. 1987); neurofilament (Diaclone, Besançon, France); cytokeratins 8, 18, 19, and 20 (all from Progen Biotechnik); ezrin (Sigma, St. Louis, Mo., USA); moesin (Transduction Laboratories, Lexington, Ky., USA); adipophilin (Progen Biotechnik; cf. Heid et al. 1998); protein p0071 (kind gift of M. Hatzfeld, University of Halle/S., Germany; Progen Biotechnik; see also Hofmann et al. 2008).

Most polyclonal antibodies used were from rabbit sera to GFAP (Dianova); VE-cadherin (Cayman Chemical, Ann Arbor, Mich., USA, via Alexis Biochemicals, Grünberg, Germany); desmoplakin (Natutec, Frankfurt, Germany); merlin (Santa Cruz); cingulin (kind gift of S. Citi, University of Geneva, Switzerland); vinculin (Sigma); $\alpha$-actinin (Sigma); tated not only the plaque proteins $\alpha$ - and $\beta$-catenin, proteins p120, and ARVCF, and plakoglobin and plakophilin-2, but also cingulin and protein ZO-1. Antibodies against VE-cadherin have precipitated complexes of this glycoprotein with $\alpha$ - and $\beta$-catenin, protein ARVCF, plakoglobin, and afadin, and protein ZO-1 and cingulin, but not N-cadherin, cadherin-11, or protein p120. Finally, note that the cadherin-11 immunoprecipitates contain $\alpha$ - and $\beta$-catenin, proteins 120 and ARVCF, and plakoglobin, but no significant amounts of $\mathrm{N}$ and VE-cadherin, plakophilin-2, L-afadin, proteins ZO-1 and ZO-2, or cingulin

perilipin (Progen Biotechnik; Heid et al. 1998). In addition, we used guinea pig antibodies against protein ARVCF (cf. Borrmann et al. 2006) and perilipin (Progen Biotechnik; cf. Heid et al. 1998; Straub et al. 2008).

Cell cultures grown on coverslips or tissue pieces were fixed with methanol and acetone, each at $-20^{\circ} \mathrm{C}$, or in buffered formaldehyde solution as described in detail elswhere (cf. Peitsch et al. 1999; Langbein et al. 2002, 2003; Schmitt et al. 2007; Rickelt et al. 2008). Protocols for light and electron microscopy and for immunolocalization microscopy were essentially as outlined in the accompanying article by Moll et al. (2008).

\section{Results and discussion}

The notion that VE-cadherin, a hallmark of endothelial differentiation and organization, can also occur, in contrast to common belief and "endothelial only" textbook dogma, in certain non-endothelial cells was initially a shock. Specific experiments, however, have subsequently shown us that AJs containing VE-cadherin indeed occur in certain other cells as constitutive structural elements. The first and, so far, most striking and consistent finding has been the occurrence of such structures in diverse cell culture lines of astrocyte and astrocytoma origin and in a subtype of glioma tumors.

VE-cadherin in human glioma cell cultures

A remarkable number of established cell culture lines derived from human gliomas exists, mostly astrocytic tumors, and in particular tumors of the glioblastoma 

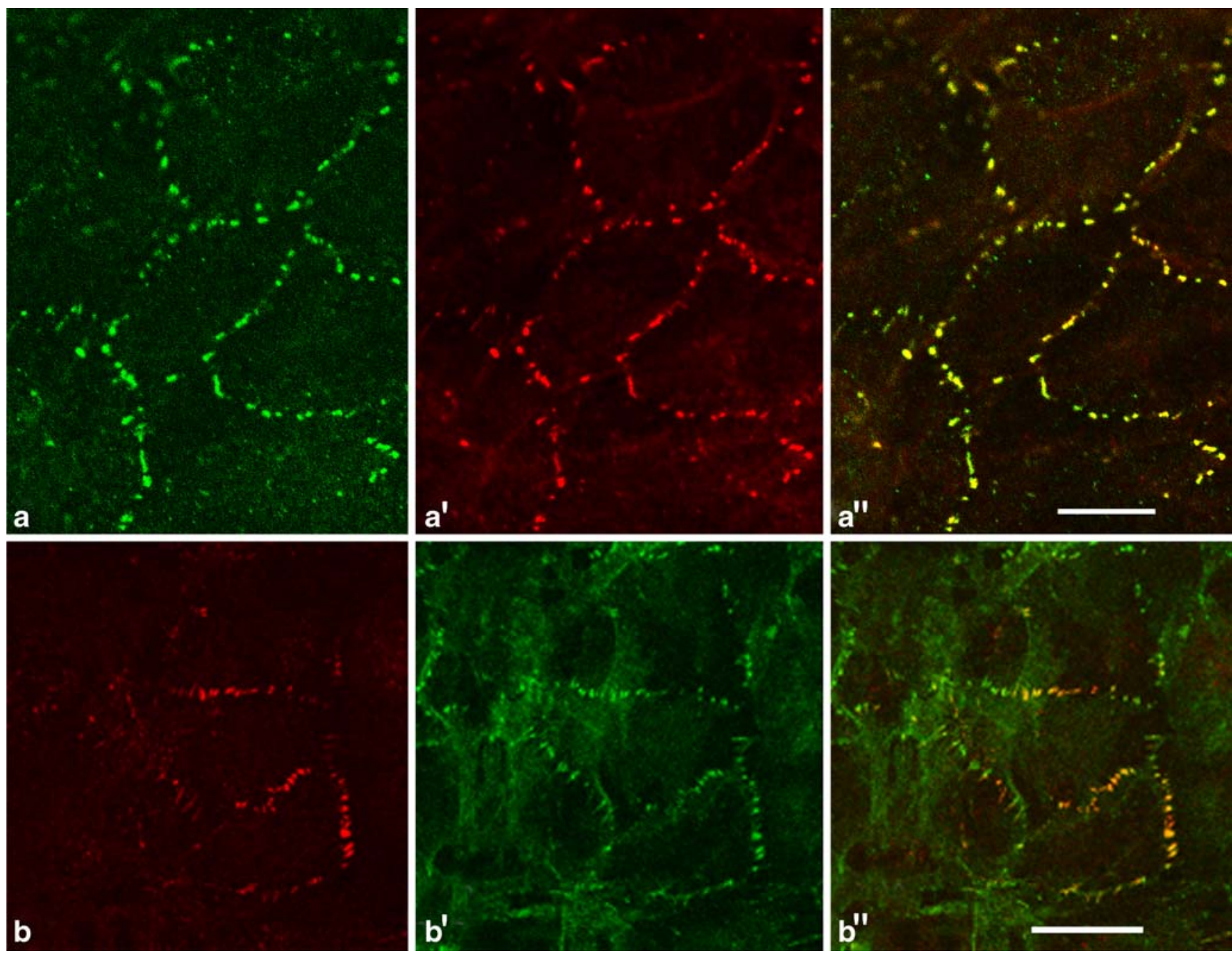

Fig. 6 Confocal laser-scanning (CLS) immunofluorescence micrographs of cultured glioma cells of line U333 as seen after reactions with antibodies against $\mathrm{N}$-cadherin (green, a) and $\alpha$-catenin (red, $\mathbf{a}^{\prime} ; \mathbf{a}^{\prime \prime}$ represents the color reaction of both channels) or with antibodies to VEcadherin $(\mathbf{b}, r e d)$ in comparison with $\alpha$-catenin $\left(\mathbf{b}^{\prime}\right.$, green; $\mathbf{b}^{\prime \prime}$ represents the hybrid color reaction of both antibodies). Note the extensive colocalization of $\mathrm{N}$-cadherin and $\alpha$-catenin in many adhering junctions (yellow colocalization in $\mathbf{a}^{\prime \prime}$ ), whereas here only certain groups of junctions show the presence of VE-cadherin together with $\alpha$-catenin (yellow in b"; e.g., reaction lower right). Bars $20 \mu \mathrm{m}$ multiforme type (see also Materials and methods). All are characterized by their differentiation marker complement. Figure 1 presents an example of glioma cells of line U333/ MG, in which all cells contain abundant bundles of intermediate-sized filaments (IFs) of the vimentin type and IFs containing GFAP (for references, see, e.g., Pontén and Westermark 1978; Paetau et al. 1980; Osborn et al. 1981; for reviews, see Kleihues and Cavenee 2000; Maher et al. 2001) and adhaerens junctions based on N-cadherin. Under normal culture conditions, these cells grow in monolayers of flat substratum-adherent cells with typical cytoplasmic actin microfilament cables and focal adhesion attachments fixing these microfilament cables to the basal plasma membrane (Fig. 2). Biochemical, molecular biological, and immunological analyses of such cells, in direct comparison with analyses of other cell cultures (Fig. 3), have revealed that the glioma U333 cells contain, in addition to the marker protein GFAP (Fig. 3b, lane 1), the AJ components N-cadherin (Fig. 3c, lane 1), VE-cadherin (Fig. 3d, d'), $\beta$-catenin (Fig. 3e), protein p120 (Fig. 3f), neurojungin (Fig. 3f'), plakophilin-2 (Fig. 3g), plakoglobin (Fig. 3h, h'), cingulin (Fig. 3i), protein ZO-1 (Fig. 3j), and protein ZO-2 (Fig. 3j').

The occurrence of VE-cadherin in glioma cells, in particular cells of astrocytic origin, is by no means restricted to tumors and the human species. Figure 4, for example, shows the synthesis of VE-cadherin in primary cultures of murine astrocytes, again occurring together with $\mathrm{N}$-cadherin (here also with cadherin-11, and the cytoplasmic plaque proteins $\alpha$ - and $\beta$-catenin, plakophilin-2, plakoglobin, protein ZO-1, ponsin, and afadin). The specific molecular complexes present in the cell-cell 


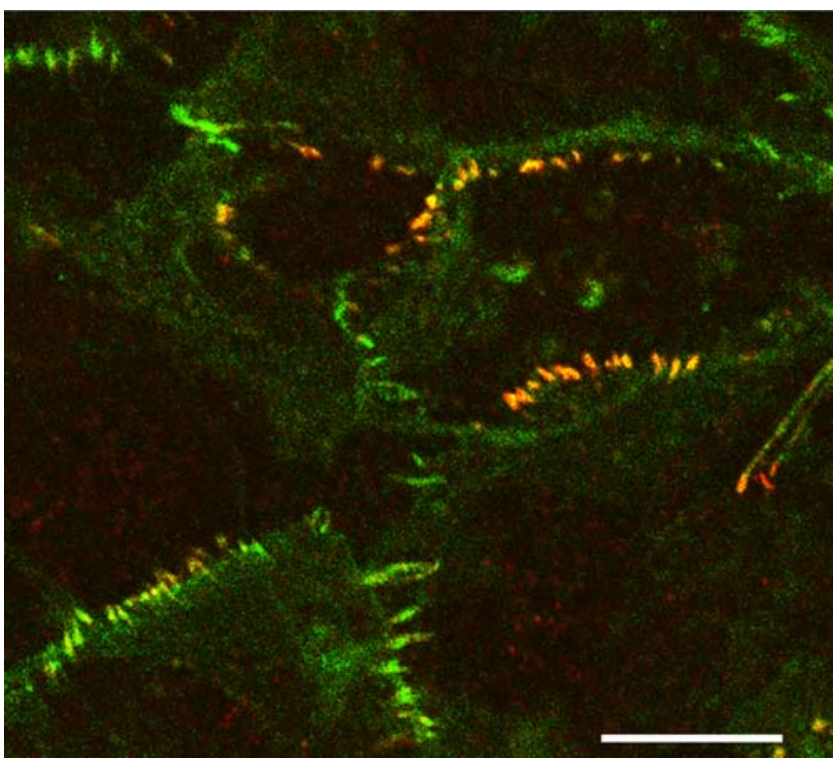

Fig. 7 CLS micrograph showing U333 glioma cells immunostained with antibodies specific for VE-cadherin (red) and $\alpha$-catenin (green). Only the merged image of both channels is shown. Note that some of the $\alpha$-catenin-containing cell junction structures are also positive for VE-cadherin (yellow), and that most of these VE-cadherin-positive junctions occur in clusters. Bar $10 \mu \mathrm{m}$

junctions of the human glioma U333 cells can be determined by immunoprecipitation experiments as presented in Fig. 5. When detergent-solubilized complexes are precipitated with antibodies to $\mathrm{N}$-cadherin, VEcadherin, or cadherin-11, co-immunoprecipitation of VEcadherin with several cadherin-anchoring plaque proteins, including $\beta$-catenin, plakoglobin, protein ARVCF, plakophilin-2, cingulin, and protein $\mathrm{ZO}-1$, are demonstrable (in a parallel experiment positive results have also been reported for $\alpha$-catenin and protein $\mathrm{p} 0071$; for details, see Boda-Heggemann 2005). Interestingly, we have not seen cross-immunoprecipitation between the three cadherins examined. On the other hand, we have to admit that we have not so far systematically varied the solubilization conditions so that we cannot yet exclude the occurrence of hetero-cadherin complexes in such junctions. However, from all our analyses, we can conclude that the AJs of the glioma type cells under question contain the cadherins and plaque proteins listed in Table 1, which also shows some differences between the three kinds of cadherin complexes precipitated.

When we examined the structures containing the various cadherins and plaque proteins with the use of confocal laser-scanning immunofluorescence microscopy, we noted that all N-cadherin-positive cell-cell junctional structures were also positive for $\alpha$ - and $\beta$-catenin (Fig. 6a-a") whereas antibodies to VE-cadherin decorated only certain regional groups ("clusters") of junctions positive for these catenins (e.g., Figs. 6b-b", 7). In extensive systematic double-label immunolocalization experiments, we could also demonstrate that not only plaque proteins of the armadillo protein family, but also, for example, cingulin, protein $\mathrm{ZO}-1$, and
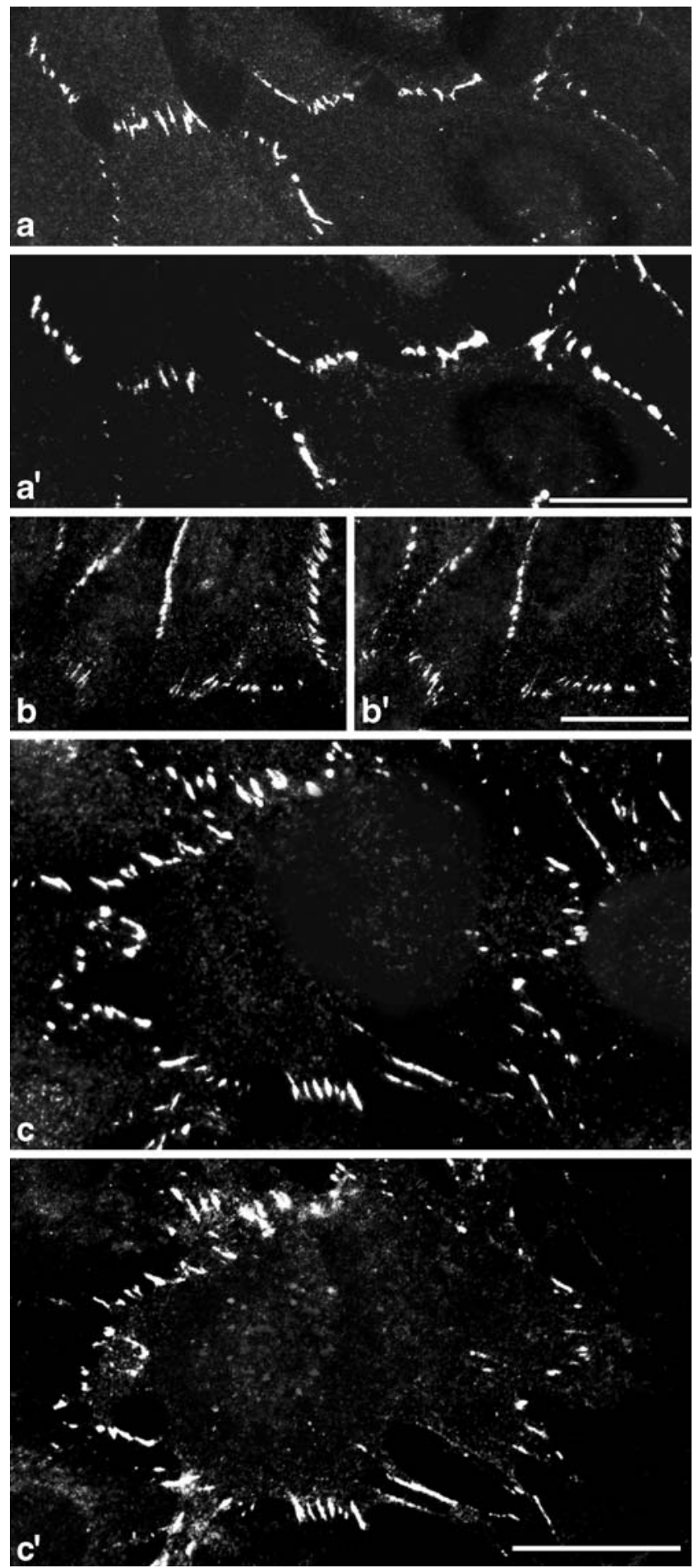

Fig. 8 CLS microscopic characterization of VE-cadherin-containing cell-cell junctions (a-c), many of which (but not all) show colocalization with cingulin $\left(\mathbf{a}^{\prime}\right)$, protein ZO-1 $\left(\mathbf{b}^{\prime}\right)$, and afadin $\left(\mathbf{c}^{\prime}\right)$. Bar $10 \mu \mathrm{m}$ 


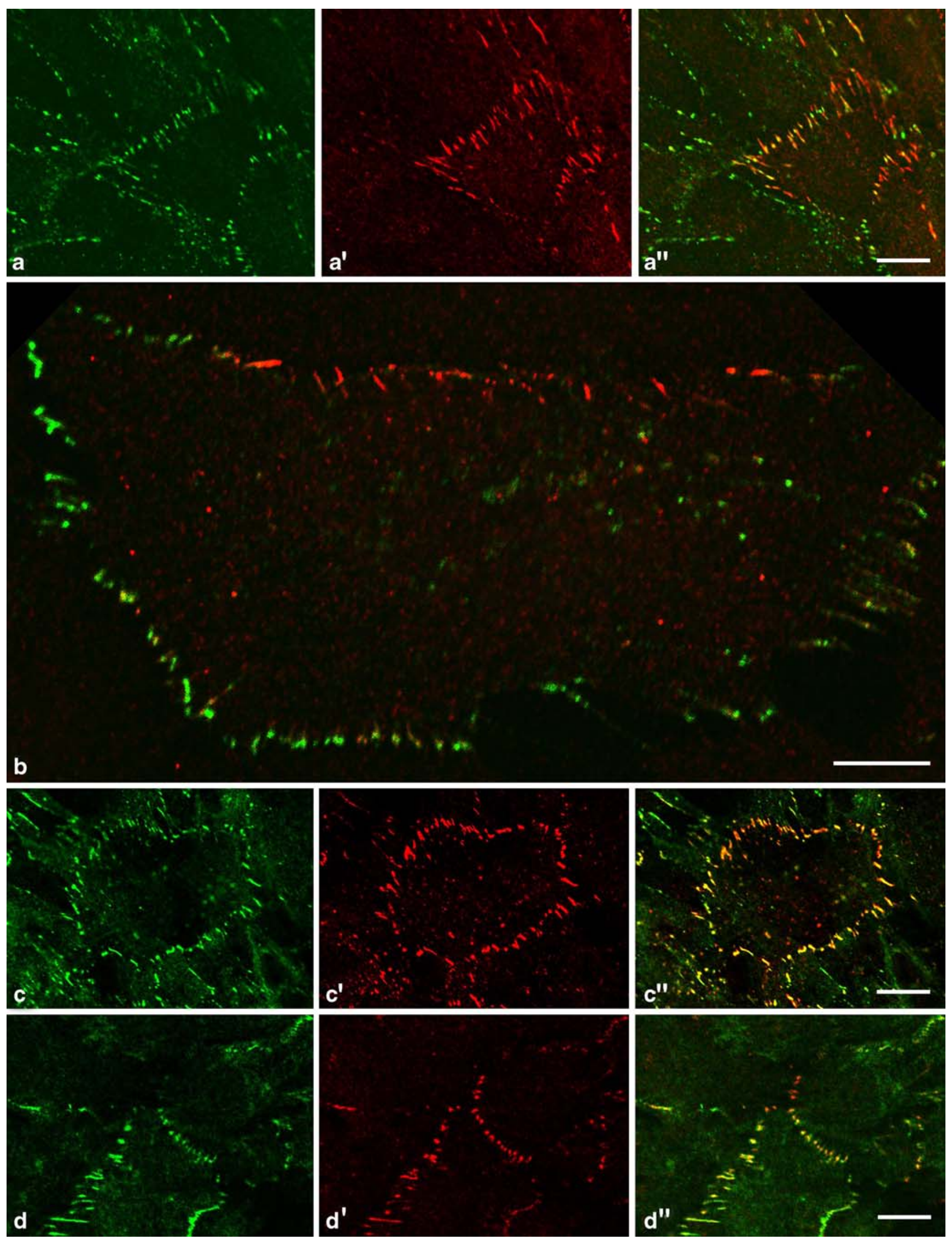


4 Fig. 9 CLS microscopy of U333 glioma cells seen after immunolocalization for N-cadherin (a-c, green) and VE-cadherin $\left(\mathbf{a}^{\prime}, \mathbf{a}^{\prime \prime}, \mathbf{b}, \mathbf{c}^{\prime}, \mathbf{c}\right.$ ", red) or for VE-cadherin (d, green) and cadherin-11 (d', $\mathbf{d}^{\prime \prime}$, red). Note that, in some junctions, N-cadherin and VE-cadherin localizations are mutually exclusive, whereas other junctions show colocalizations (a", b, $\mathbf{c}^{\prime \prime}$, seen as yellow-orange in $\left.\mathbf{a}^{\prime \prime}, \mathbf{c}^{\prime \prime}\right)$. Note also the regional segregation of VE-cadherin- and N-cadherincontaining junctions (particularly clear at higher magnification in $\mathbf{b}$ ). In addition, double-labelling for VE-cadherin (d, green) and cadherin$11\left(\mathbf{d}^{\prime}\right)$ shows regions with junctions of mutual exclusivity and some with colocalization (d", yellow). Bars $10 \mu \mathrm{m}$

afadin were colocalized (see Figs. 6, 7, 8). In general, colocalization of two junctional components was frequent but, in the same cell colony, regions characterized by only one junctional protein without a frequent partner could not be overlooked.

Colocalization of these components (see also Table 1) could also be detected in various combinations (see Figs. 8, 9). Figure 10, for example, presents a cell with a predominance of AJs showing near-complete co-localization of cadherin-11 and plakophilin-2, and the precision of double-label coincidence can be seen with special clarity in the insets (upper right in Fig. 10a-a"). In other words, we have found no indication of systematic mutual exclusivity in the AJ localization of these three cadherins, either amongst each other or with respect to colocalization with one of the various plaque proteins.

\section{Junction type heterogeneity and domain segregations}

in VE-cadherin-positive glioma cell junctions

In these studies, our attention was particularly attracted by two hitherto unseen phenomena. First, in the same monolayer culture of glioma cells in which VE-cadherin localized, in most cells, to groups of N-cadherin-positive junctions, neighboring cells were detected that were positive for N-cadherin only (e.g., Fig. 9a-a", c-c"), indicating that VE-cadherin assembly into heterotypic junctions is a process that may occur locally and highly selectively in some cells but not in others.

The second remarkable phenomenon that was repeatedly observed was the segregation of $\mathrm{N}$-cadherin-containing and VE-cadherin-containing AJs to different surface domains of the same cell (e.g., Fig. 9b). Such localization results obviously suggest that the surfaces of these cells can appear as a checker-board or can even be totally polarized into relatively large regions or "hemispheres": one N-cadherindominated domain and one VE-cadherin region.

Finally, even a third type of cadherin-localization can be noted (e.g., Fig. 9d-d"). Here, neighboring cells can be connected to each other in one region by junctions of the $\mathrm{N}$ cadherin-only character, and in another region by junctions positive for VE-cadherin only, and in a third category of domain by mixed type junctions that are positive for both cadherins. The relatively frequent occurrence of plakophilin2 in such AJs is also remarkable (for special junction plaque organizing roles of this protein, see, e.g., also Mertens et al. 1996, 1999; Grossmann et al. 2004; Franke et al. 2006; Goossens et al. 2007; Oxford et al. 2007).

Our surprise that VE-cadherin regularly occurred in nonvascular cells and apparently not necessarily as a clonally stable property, but as repeatedly and cell-specifically occurring synthesis and junction assembly events (at random or locally induced) prompted us to undergo a more extensive study of these phenomena.

The identification of the various junction molecules was initially based on immunological identification by immunoblot and immunofluorescence localization experiments. The highly sensitive method of reverse transcription with polmerase chain reaction (RT-PCR) then confirmed the significance and specificity of the synthesis of VE-cadherin in the cultured glioma cells (Fig. 11). VE-cadherin was detected in the glioma cells and in bovine and human endothelial cells growing in culture but was absent in a series of other cells examined in parallel (Fig. 11a). Moreover, the specific synthesis of VE-cadherin was also
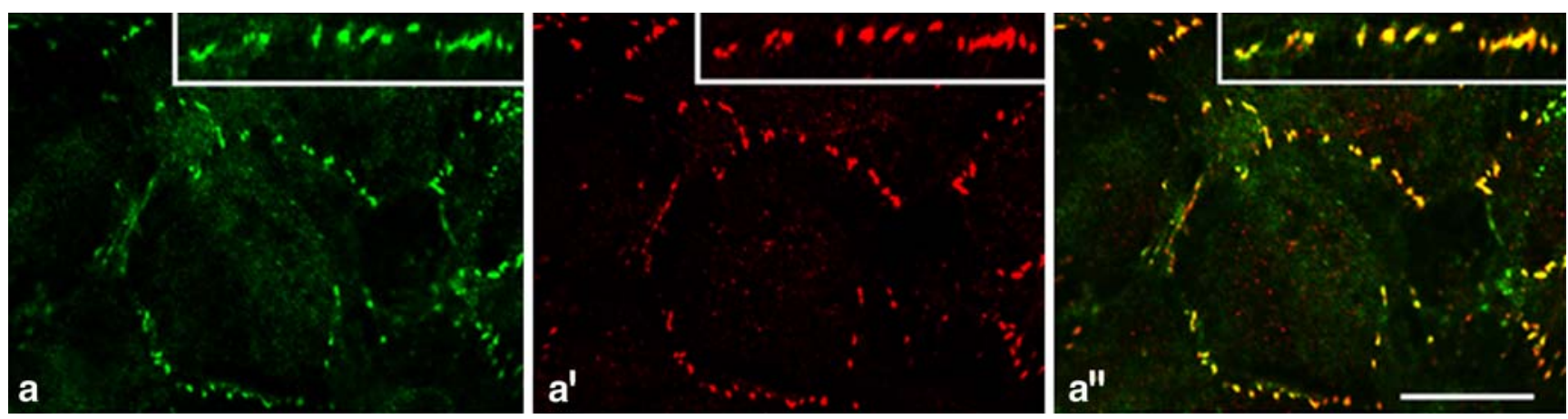

Fig. 10 CLS micrographs showing the frequent colocalization of cadherin-11 (a) with plakophilin-2 ( $\left.\mathbf{a}^{\prime}\right)$ as indicated by the yellow-orange merge color $\left(\mathbf{a}^{\prime \prime}\right)$. This can be seen with special clarity in the higher magnification insets upper right. Bar $10 \mu \mathrm{m}$ 

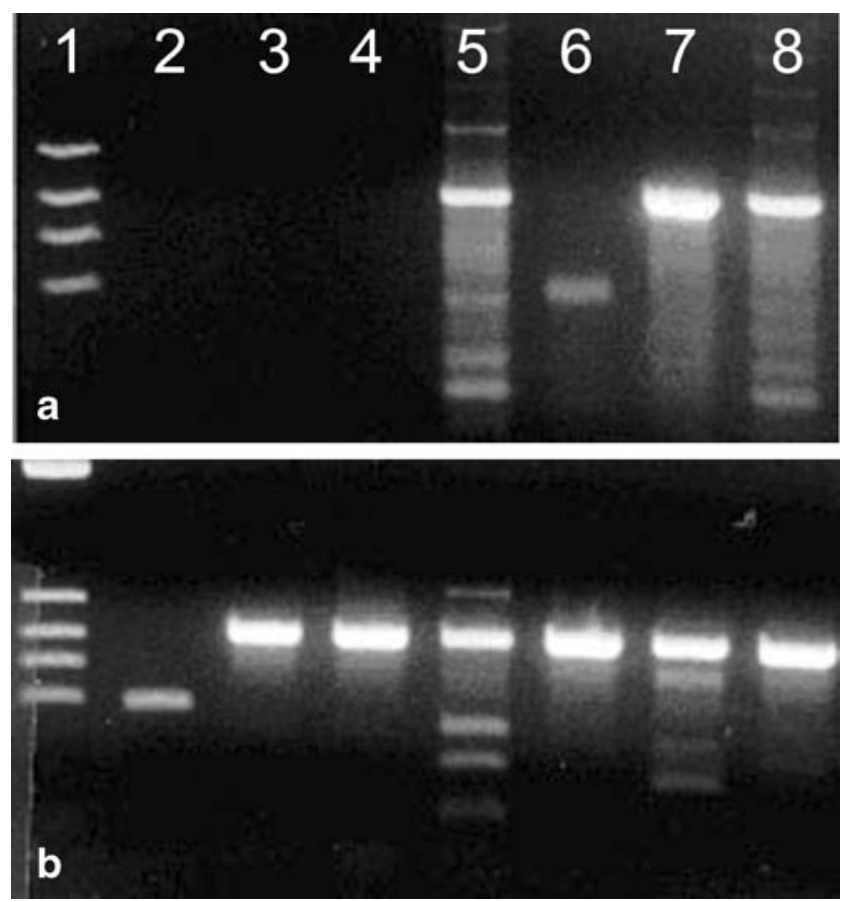

Fig. 11 Demonstration of VE-cadherin mRNAs by reverse transcription with polymerase chain reaction (RT-PCR) in specific cell cultures. a VE-cadherin mRNA was detected as 400-bp DNA in human U333 glioma cells (lane 8), in calf pulmonary artery endothelial (CPAE) cells (lane 5), and human umbilical cord endothelial cells (HUVEC, lane 7), but not in diverse other cells (lane 6 human breast carcinoma cells of line MCF-7). Other negative controls shown are cell material without template (lane 2), without sense-primer (lane 3), or without antisenseprimer (lane 4). Lane 1 contains size references of 517, 396, 356 and 247 bp. b Demonstration of VE-cadherin mRNA as a 400-bp DNA fragment in diverse cell cultures such as human HUVEC cells (lanes 3, 4; see also above), primary cultures of mouse astrocytes (lane 5), human glioblastoma cells of lines T98G (lane 6), U373MG (lane 7), and U333 glioma cells (lane 8). The negative control (lane 2) contains material from human colon carcinoma cells of line $\mathrm{CaCo}-2$. Lane 1 contains DNA size standards (as in a, lane 1)

noted in other cell lines of glioma cells and in primary cell cultures of mouse astrocytes (Fig. 11b). These and several other gene expression experiments have led us to the conclusion that the emergence of the synthesis of VEcadherin is not a trivial and widespread result of "loose" or "leaky" gene control, as has been reported for other cytoskeletal proteins in diverse cell cultures (e.g., Knapp and Franke 1989; Knapp et al. 1989; and references cited therein) but is the result of specific gene induction in these glioma cells.

The RT-PCR method also allowed us to detect some additional components of the AJs of the glioma cells such as the armadillo type plaque protein p0071 (Fig. 12, lane 4), which in parallel was also demonstrable in cultures of human mesenchymal stem cells, endothelial cells, and other cells and tissues. This AJ protein 0071 has since also been immunolocalized to the AJs of these glioma cells (see also Hofmann et al. 2008).
VE-cadherin in adhering junctions of primary cultures of astrocytes

The appearance of VE-cadherin is not confined to astrocytomas and related malignancies. The intense reaction of mRNA encoding VE-cadherin has previously been demonstrated by RT-PCR analyses of normal murine astrocytes (Fig. 11b, lane 5). The specific localization of VE-cadherin in the AJs of primary cultures of such astrocytes has also been demonstrated by immunofluorescence microscopy (Fig. 13); the reactions of AJs are shown with antibodies to VE-cadherin (Fig. 13c), in comparison with $\mathrm{N}$-cadherin (Fig. 13b), plakophilin-2 (Fig. 13d), protein ZO-1 (Fig. 13e), and ponsin (Fig. 13f) in cell cultures identified as astrocytes by their intense GFAP decoration (Fig. 13a). A certain subpopulation of such AJs also exhibits positive reaction for cadherin-11 (not shown). We therefore conclude that VE-cadherin can be synthesized in normal astrocytes and integrated with $\mathrm{N}$-cadherin and/or cadherin11 into normal-looking AJs.

The formation of various types of adhering junctions in the same cell and their segregation to homotypic clusters in different cell surface regions are intrinsic properties of a given glioma cell type

In order to examine whether the formation of VE-cadherincontaining AJs and of the regional segregation of $\mathrm{N}$-cadherin versus VE-cadherin domains in cultured glioma cells are general and stable properties of defined and distinct glioma cell subtypes, or whether they represent the emergence of specific clonal subtypes during the long cell culturing period, we have systematically cloned individual cells of glioma line

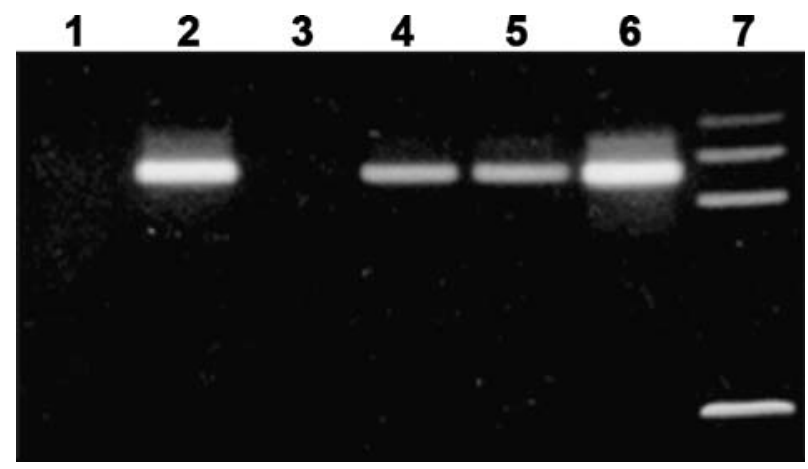

Fig. 12 RT-PCR demonstrating the junctional (AJ) plaque protein p0071 in human glioma U333 cells (lane 4), in comparison with human bone marrow-derived cultured mesenchymal stem cells (MSC, lane 5), human umbilical cord-derived endothelial cells (line HUVEC, lane 6) and human liver carcinoma cells of line PLC (lane 3; here the reaction is weak and only seen upon prolonged exposure), in comparison with tissues of human heart (lane 2) and of bovine eye lens (lane 1; for the negative reaction, see also Straub et al. 2003). Lane 7 shows DNA size markers (Hinf-1 digest, bluescribe vector) 

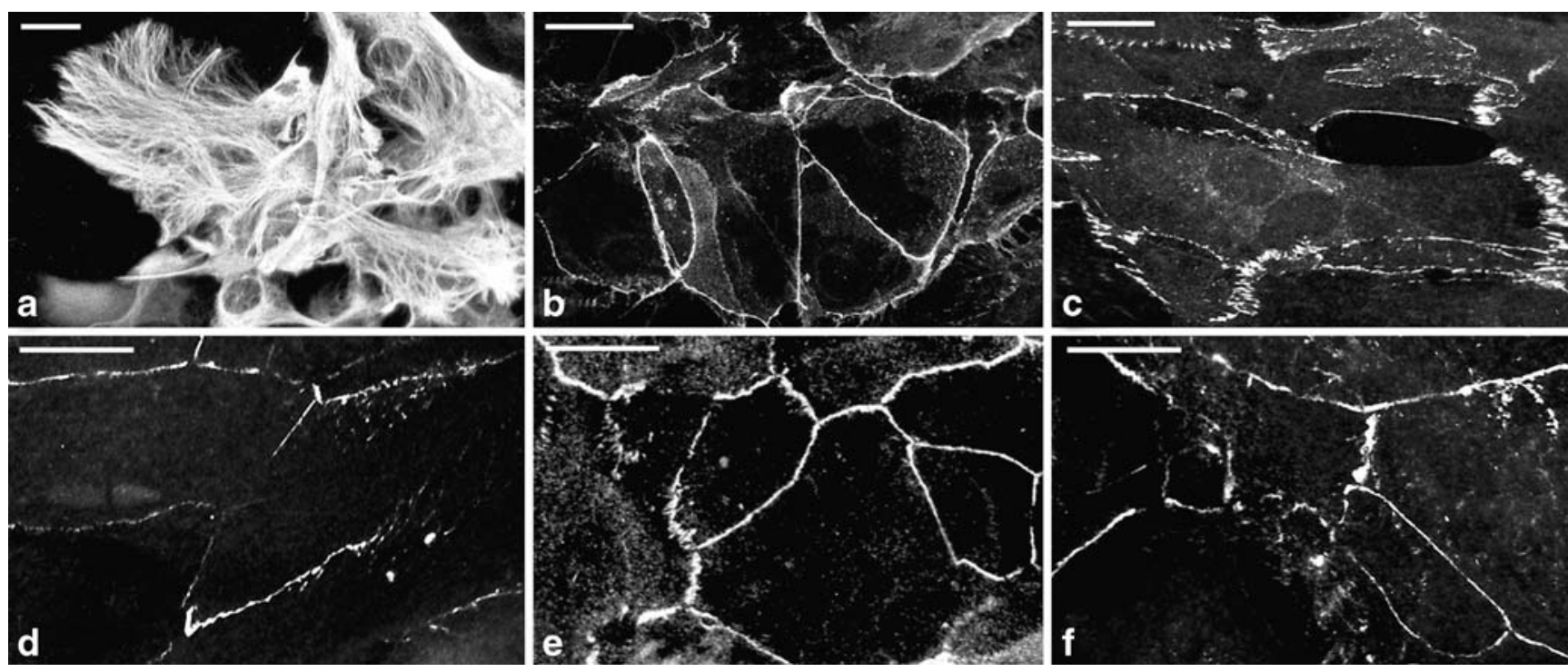

Fig. 13 Immunofluorescence microscopical characterization of primary murine astrocyte cultures with antibodies against GFAP (a) and $\mathrm{N}$-cadherin (b). The adhering junctions present in these cells also

U333 and generated clonal sublines (for methods, see Knapp and Franke 1989). Some results are presented in Figs. 14, 15. Clearly, regional segregation into VEcadherin-positive versus $\mathrm{N}$-cadherin-positive domains are frequently seen among the progeny of such clones, even after only a few cell generations (Fig. 14). Examples of both marked cell-to-cell heterogeneity and regionalization of the different $\mathrm{AJ}$ subtypes in the same cell have been noted in some of the clonal subcultures (e.g., Fig. 15). In such clonally derived cell colonies, regions of an exclusive VE-cadherin character can be recognized in addition to domains with AJs containing $\mathrm{N}$-cadherin only and other AJs that display a true hybrid character as they are intensely positive for both $\mathrm{N}-$ and VE-cadherin (Fig. 15; see, in particular, the insets). Consequently, we conclude that the abilities to form $\mathrm{AJs}$ of different cadherin compositions and to segregate different AJ subtypes to different domains is an intrinsic property and a variability potential of such glioma cells.

VE-cadherin as an immunohistochemical marker for certain subtypes of astrocytes and astrocytomas

in neuropathological diagnoses

The occurrence of VE-cadherin-positive AJs along cellcell borders of astrocytomas and related tumors is not only observed in cultured cells, but can also be seen in situ, as is demonstrated by the immunohistochemistry of the high-grade glioblastoma multiforme tumor shown in Fig. 16. Here. practically all identifiable glioma cells react contain VE-cadherin (c), plakophilin-2 (d), protein ZO-1 (e), and ponsin (f). Bar $20 \mu \mathrm{m}$

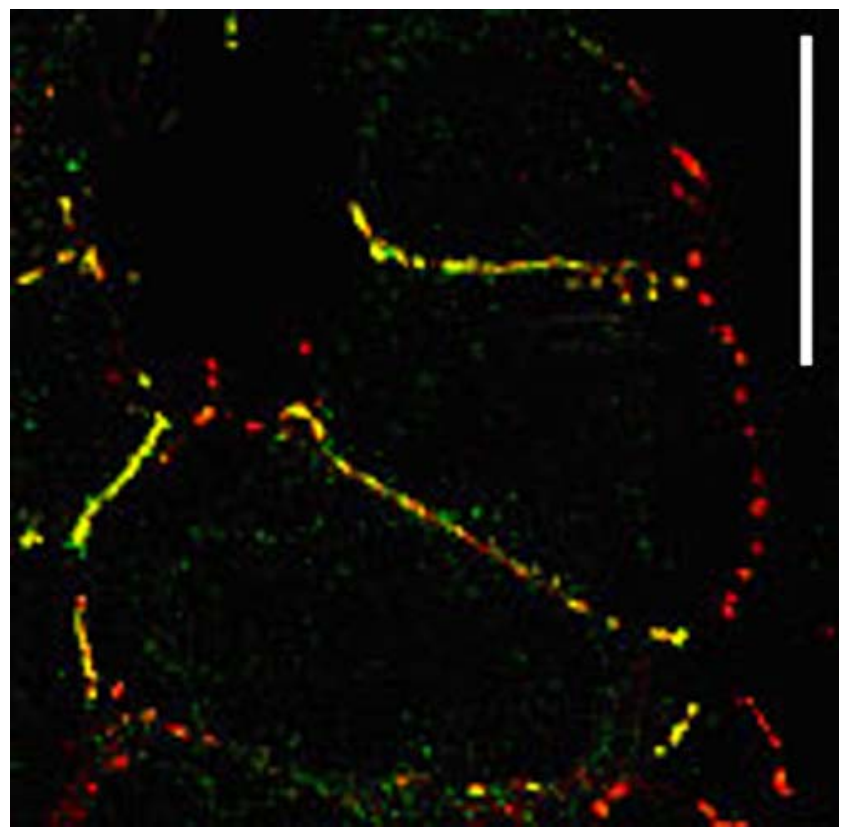

Fig. 14 CLS double-label immunofluorescence micrograph showing a monolayer of cells in a culture of progeny of a single U333 glioma cell clone (no. 20); immunoreaction with antibodies to $\mathrm{N}$-cadherin (red) and cadherin-11 (green). Note some heterogeneity not only of the cells, but also of the different plasma membrane domains within the same cell. Cell domains connected to neighboring cells with only $\mathrm{N}$-cadherin-positive AJs are present (e.g., red, right) as are other domains positive for both cadherins (yellow-orange) and certain small AJs positive for only cadherin-11 (green), which are interspersed between the yellow domains, i.e. mixed type junctions containing both kinds of cadherins. Bar $20 \mu \mathrm{m}$ 


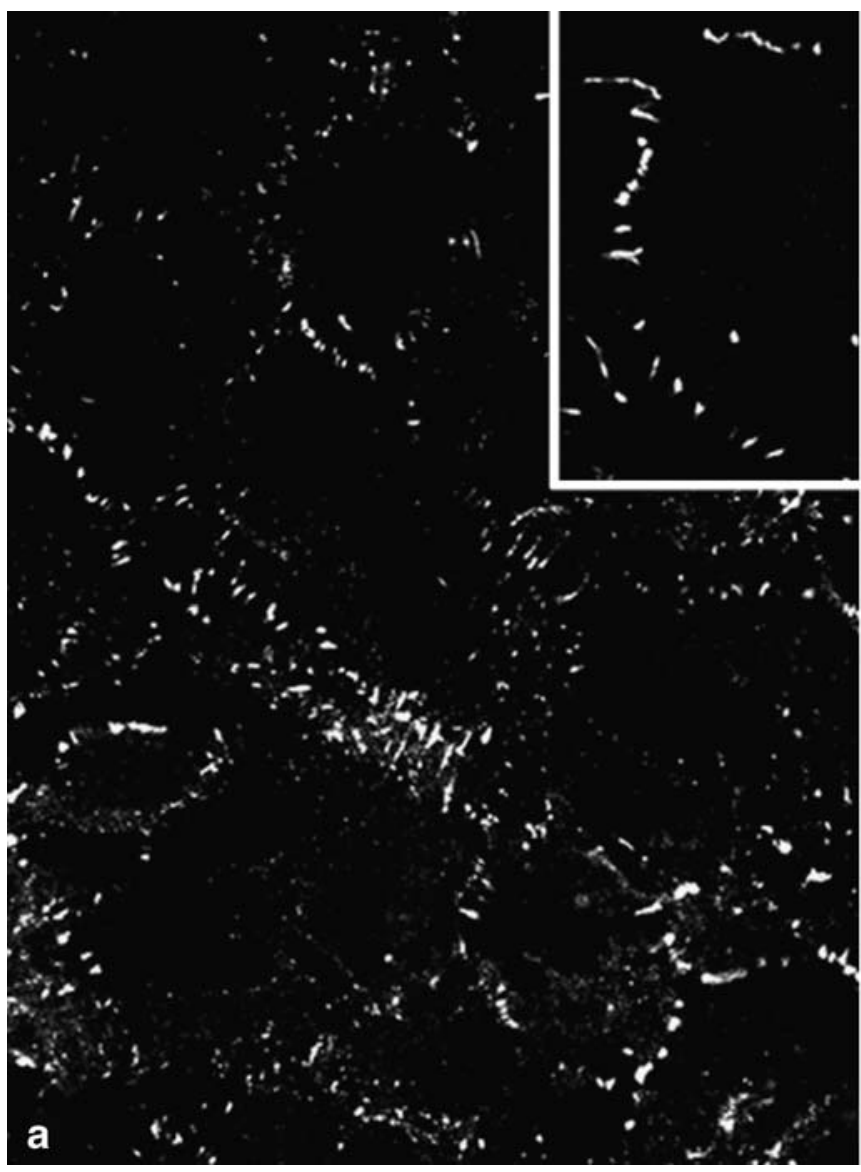

Fig. 15 CLS immunofluorescence microscopy of U333 glioma cells, showing the progeny of a single $\mathrm{N}$-cadherin-positive cell clone (no. 43; cf. Boda-Heggemann 2005), here with the remarkable reappearance of high complexity and heterogeneity in the resulting clonal culture. Note the different subtypes of glioma cells that have formed again as individual cells. Moreover, many, but by no means

with antibodies to GFAP, which is accompanied in almost all cells by intense $\mathrm{AJ}$ reactions with antibodies against $\mathrm{N}$ cadherin and with antibodies against VE-cadherin.

This, however, is by no means a general characteristic of gliomas. Indeed, in our hands, only a small proportion of gliomas examined by immunohistochemistry have shown VE-cadherin positivity. Systematic determinations will now have to be carried out in order to ascertain the extent to which this glioma subtype is biochemically, biologically, and clinically different from other glial tumors. It will be particularly important to test whether other typical endothelial molecular "markers" can also be detected in the VE-cadherinpositive or other subtypes of glial tumors, and in which way the tumor-accompanying vasculogenesis is correlated (chronologically, developmentally, and topologically) with the spread and the metastatic progression of such tumors, notably glioblastomas (for a review, see Kleihues and Cavenee 2000).

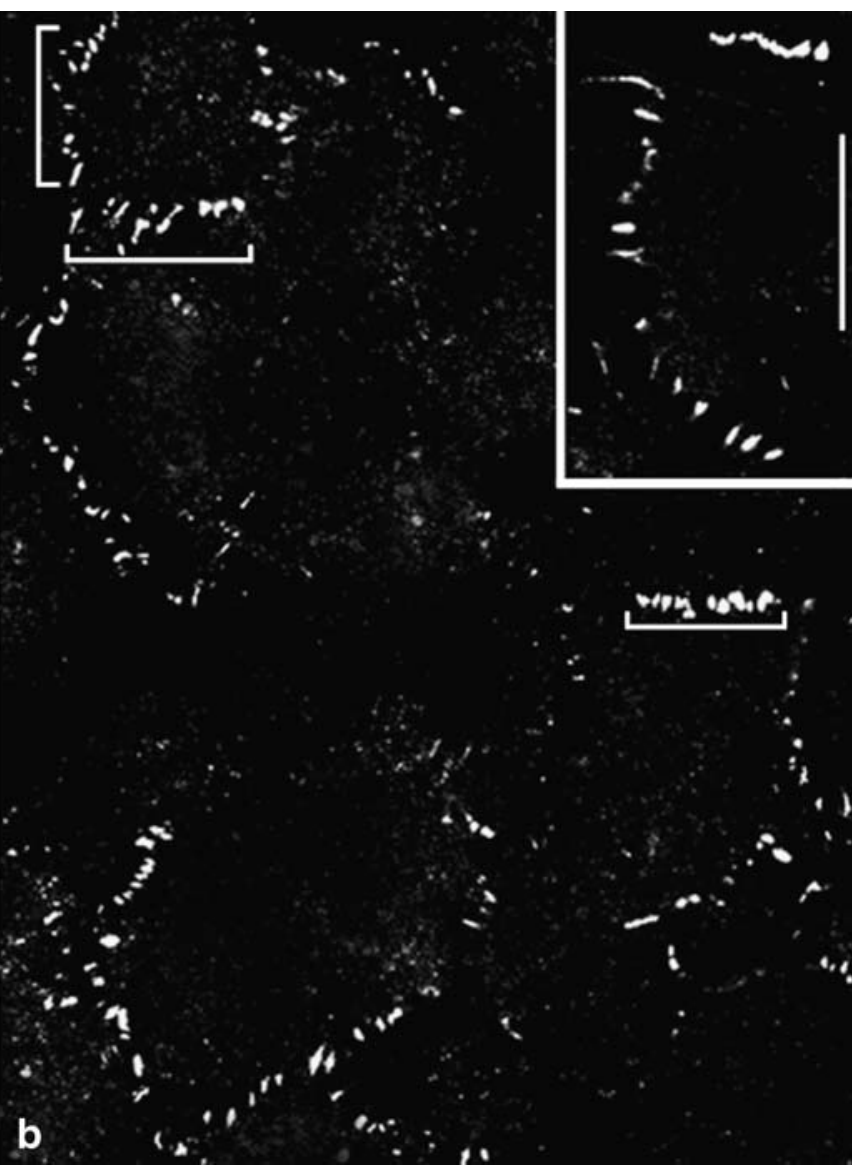

all, of the AJs positive for N-cadherin (a) are also positive for VEcadherin (b). In addition to $\mathrm{N}$ :VE-cadherin hybrid AJs, strictly $\mathrm{N}$ cadherin- or VE-cadherin-positive AJs can also be seen (see brackets in b). Insets: Higher magnification of N:VE-cadherin hybrid AJs. Bar $20 \mu \mathrm{m}$

VE-cadherin-containing astrocytes and glioma tumors: biological, pathological, and potential clinical problems

The occurrence of AJs containing VE-cadherin in a series of glioma cell culture lines and in certain normal astrocytes and some glioma tumors in situ may, at first sight, seem to reflect bizarrely irregular protein synthesis and structure assembly. However, a remarkably large body of literature links astrocytes and astrocyte products, both spatially and as regards molecular and developmental aspects, to blood vessels, in particular endothelial cells. Indeed, as early as 1981, the anthology entitled "Glial-neurone interactions" by J. Treherne (1981) presented, on its cover, a schematic drawing of an astrocyte with its processes attached to a neuron on the one side and a blood vessel on the other; this book included a number of relevant articles on interactions between astrocytes and endothelial cells in vertebrates and invertebrates (e.g., Landis and Reese 1981; Lane 1981; Lasek and Tytell 1981; Roots 1981; Somjen 1981). Soon 


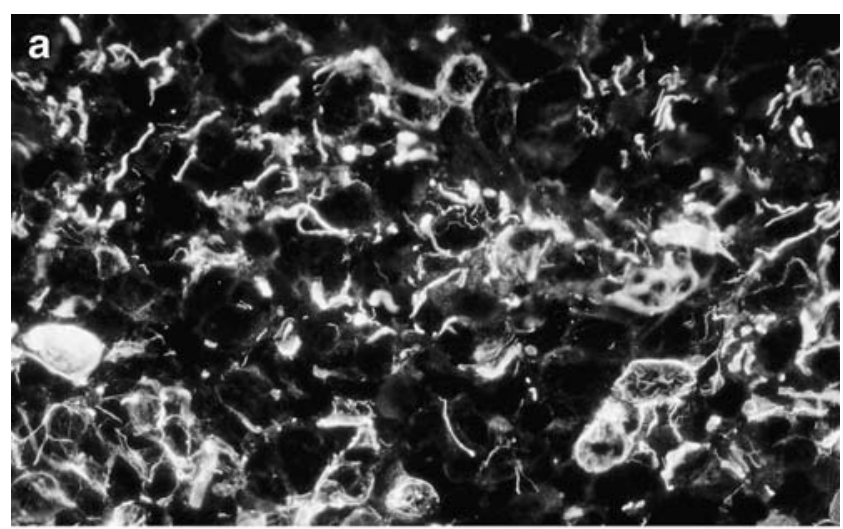

et al. 2003; Hamm et al. 2004; Takano et al. 2006). Researchers in this field have apparently been especially impressed by the angiogenic and vasculogenic effects of glioma cells (e.g., Plate and Risau 1995; Bian et al. 2000; Carmeliet and Jain 2000; Maher et al. 2001; Miebach et al. 2006), and the pathogenic cross-talk of glial and endothelial cells has also been reported (e.g., Liebner et al. 2000; Nico et al. 2003). On the other hand, direct AJ contacts between these two cell types and the occurrence of VE-cadherin in AJs of adjacent astrocytes or glioma cells have not yet been observed.

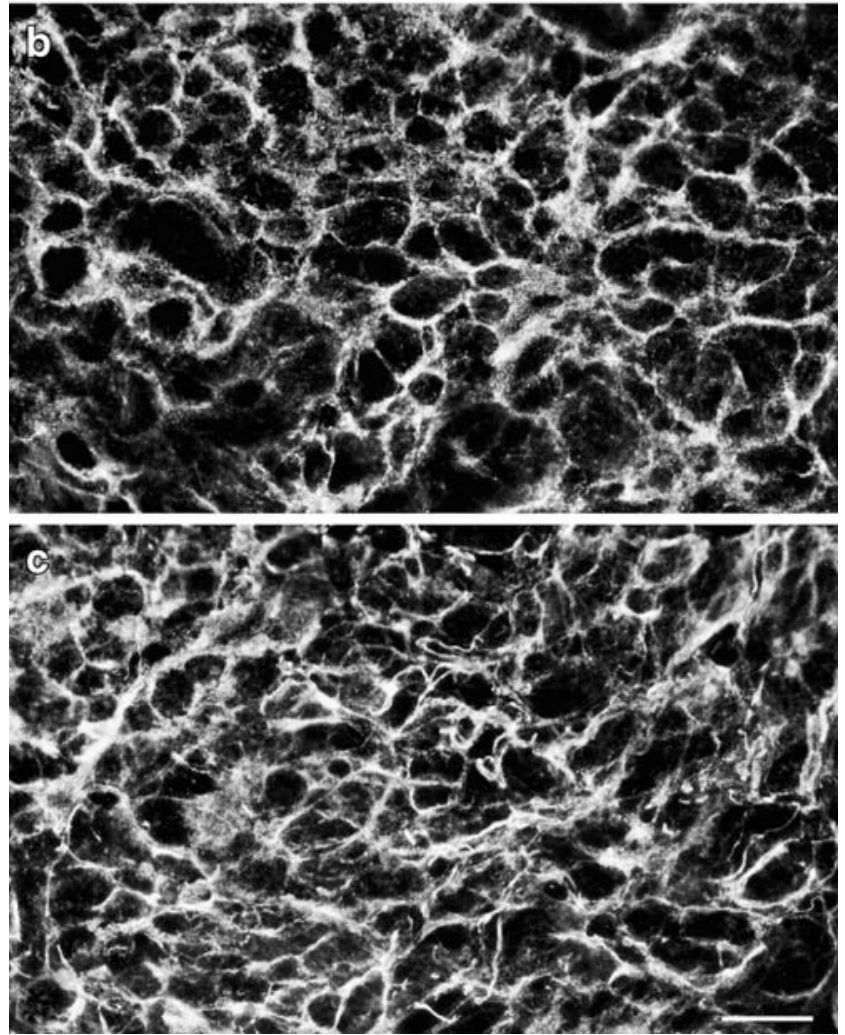

Fig. 16 Immunofluorescence microscopy of cryostat sections through a human glioma in situ (high-grade glioblastoma multiforme: grade IV). In this tumor, almost all cells are positive for GFAP (a), Ncadherin (b), and VE-cadherin (c). Bar $20 \mu \mathrm{m}$

thereafter, Bär (1983) reviewed the literature on the interrelationship of these two cell types and introduced the concept of "glio-vascular contacts". In general, cell-cell contacts and secreted factors of astrocytes promoting and regulating the growth of endothelial cells and the formation of vascular architecture have been repeatedly described in experiments with cultured cells (specifically co-culture systems) and in situ, and the effects of astrocytes on junctions and on the functioning of the blood-brain-barrier have received special attention (e.g., Stewart and Wiley 1981; Risau et al. 1986; Janzer and Raff 1987; Wolburg et al. 1994; Cecchelli et al. 1999; Brillault et al. 2002; Nico
VE-cadherin as a constitutive component of cell-cell junctions in a special type of melanoma

Hendrix and collaborators have reported and characterized a highly aggressive subtype of melanoma of both cutaneous and uveal origin; this subtype is distinguishable from other melanoma forms by the presence of biochemically and immunocytochemically demonstrable VE-cadherin, which is enriched in the variously sized AJs of such cells (Hendrix et al. 2001, 2003; Hess et al. 2001, 2006; Seftor et al. 2002; for details, see also Maniotis et al. 1999; Folberg et al. 2000). Remarkably, melanomas of this subtype are often also drastically enriched in another group of endothelial markers, viz., receptor tyrosine kinases (TIE-1, EphA2), enzymes known to be also synthesized in impressive amounts in the vessels serving astrocytomas and glioblastomas (for a review, see Cavenee et al. 2000). Therefore, Hendrix et al. (2001; see also Maniotis et al. 1999; Folberg et al. 2000) have introduced the term "vasculogenic mimicry" for the appearance of such tumors with specific endothelial markers; these authors have also been able to down-regulate the VE-cadherin concentration and to abrogate, with molecular tools, the ability of these melanoma cells to form vascular capillary-like tubular structures, a characteristic differentiation form of this melanoma cell subtype.

\section{Concluding remarks}

The general dogma that "VE-cadherin is endothelialspecific" (e.g., Cavallaro et al. 2006) has held until today. Obviously, here, as is all too often the case in cell and molecular biology, the analysis books have been closed too early. Although, in recent years, good careful biochemical analyses and the resulting novel findings are of low esteem and have earned pejoratives such as "archival", "descriptive", or "non-mechanistic", a logical request can be made for the creation of a correct and solid analytical fundament before valid functional hypotheses are formulated. With the unexpected findings of VE-cadherin in certain astrocytes 
and glioma cell types and in a subtype of melanoma, we must now start a thorough re-examination of the possible occurrence of this cadherin in further cell types, including those involved in diseases. The VE-cadherin-containing AJs of certain astrocyte- and melanocyte-derived tumor cells could heterotypically but trans-homophilically be attached to vascular endothelial cells and tumors with a particularly rich vascular system; gliomas and melanomas are certainly good candidates for such attachment. Moreover, our findings of the regional segregation and polar clustering of specific subforms of AJs, the VE-cadherincontaining types included, now indicate that connections between cells, including those that are malignant, may differ in molecular character on different parts of the cell surface. The surprising findings of junctions containing VE-cadherin in non-endothelial cells have thus created more questions than answers.

Open Access This article is distributed under the terms of the Creative Commons Attribution Noncommercial License which permits any noncommercial use, distribution, and reproduction in any medium, provided the original author(s) and source are credited.

\section{References}

Achtstätter T, Moll R, Anderson A, Kuhn C, Pitz S, Schwechheimer K, Franke WW (1986) Expression of glial filament protein (GFP) in nerve sheaths and non-neural cells re-examined using monoclonal antibodies, with special emphasis on the coexpression of GFP and cytokeratins in epithelial cells of human salivary gland and pleomorphic adenomas. Differentiation 31:206-227

Angst BD, Marcozzi C, Magee AI (2001) The cadherin superfamily: diversity in form and function. J Cell Sci 114:629-641

Bär T (1983) Patterns of vascularization in the developing cerebral cortex. Ciba Found Symp 100:21-36

Behrens J, Birchmeier W, Goodman SL, Imholf BA (1985) Dissociation of Madin-Darby canine kidney epithelial cells by the monoclonal antibody anti-arc-1: mechanistic aspects and identification of the antigen as a component related to uvomorulin. J Cell Biol 101:1307-1315

Behrens J, Vakaet L, Friis R, Winterhager E, Roy F van, Mareel MM, Birchmeier W (1993) Loss of epithelial differentiation and gain of invasiveness correlates with tyrosine phosphorylation of the Ecadherin/ $\beta$-catenin complex in cells transformed with a temperature-sensitive v-src gene. J Cell Biol 120:757-766

Bian XW, Du LL, Shi JQ, Cheng YS, Liu FX (2000) Correlation of bFGF, FGFR-1 and VEGF expression with vascularity and malignancy of human astrocytomas. Anal Quant Cytol Histol 22:267-274

Boda-Heggemann J (2005) Zell- und molekularbiologische Charakterisierung neuartiger Zell-Zell-Verbindungsarten in Glioma-Zellen und mesenchymalen Stammzellen. Ph.D. Thesis, Faculty of Biology, University of Heidelberg, Germany (URL: http://www. ub.uni-heidelberg.de/archiv/6127)

Borrmann CM, Grund C, Kuhn C, Hofmann I, Pieperhoff S, Franke WW (2006) The area composita of adhering junctions connecting heart muscle cells of vertebrates. II. Colocalizations of desmo- somal and fascia adhaerens molecules in the intercalated disk. Eur J Cell Biol 85:469-485

Boukamp P, Petrussevska RT, Breitkreutz D, Hornung J, Markham A, Fusenig NE (1988) Normal keratinization in a spontaneously immortalized aneuploid human keratinocyte cell line. J Cell Biol 106:761-771

Brillault J, Berezowski V, Cecchelli R, Dehouck M-P (2002) Intercommunications between brain capillary endothelial cells and glial cells increase the transcellular permeability of the blood-brain barrier during ischaemia. J Neurochem 83:807-817

Burudi EM, Riese S, Stahl PD, Regnier-Vigouroux A (1999) Identification and functional characterization of the mannose receptor in astrocytes. Glia 25:44-55

Carmeliet P, Jain RK (2000) Angiogenesis in cancer and other diseases. Nature 407:249-257

Carmeliet P, Lampugnani MG, Moons L, Breviario F, Compernolle V, Bono F, Balconi G, Spagnuolo R, Oostuyse B, Dewerchin M, Zanetti A, Angellilo A, Mattot V, Nuyens D, Lutgens E, Clotman F, Ruiter MC de, Gittenberger-de Groot A, Poelmann R, Lupu F, Herbert JM, Collen D, Dejana E (1999) Targeted deficiency or cytosolic truncation of the VE-cadherin gene in mice impairs VEGF-mediated endothelial survival and angiogenesis. Cell 98:147-157

Cavallaro U, Liebner S, Dejana E (2006) Endothelial cadherins and tumor angiogenesis. Exp Cell Res 312:659-667

Caveda L, Martin-Padura I, Navarro P, Breviario F, Corada M, Gulino D, Lampugnani MG, Dejana E (1996) Inhibition of cultured cell growth by vascular endothelial cadherin (cadherin-5/VE-cadherin). J Clin Invest 98:886-893

Cavenee WK, Furnari FB, Nagane M, Huang H-JS, Newcomb EW, Bigner DD, Weller M, Berens ME, Plate KH, Israel MA, Noble MD, Kleihues P (2000) Diffusely infiltrating astrocytomas. In: Kleihues P, Cavenee WK (eds) Pathology and genetics of tumours of the nervous system (WHO Classification of Tumours). IARC Press, Lyon, pp 10-21

Cecchelli R, Dehouck B, Descamps L, Fenart L, Buée-Scherrer V, Duhem C, Lundquist S, Rentfel M, Torpier G, Dehouck MP (1999) In vitro model for evaluating drug transport across the blood-brain barrier. Adv Drug Deliv Rev 36:165-178

Cowin P, Kapprell HP, Franke WW, Tamkun J, Hynes RO (1986) Plakoglobin: a protein common to different kinds of intercellular adhering junctions. Cell 46:1063-1073

Dejana E (1996) Endothelial adherens junctions: implications in the control of vascular permeability and angiogenesis. J Clin Invest 98:1949-1953

Dejana E (2004) Endothelial cell-cell junctions: happy together. Nat Rev Mol Cell Biol 5:261-270

Dejana E, Bazzoni G, Lampugnani MG (1999) Vascular endothelial (VE)-cadherin: only an intercellular glue? Exp Cell Res 252:13-19

Farquhar MG, Palade GE (1963) Junctional complexes in various epithelia. J Cell Biol 17:375-412

Folberg R, Hendrix MJC, Maniotis AJ (2000) Vasculogenic mimicry and tumor angiogenesis. Am J Pathol 156:361-381

Franke WW, Schmid E, Osborn M, Weber K (1978) Different intermediate-sized filaments distinguished by immunofluorescence microscopy. Proc Natl Acad Sci USA 75:5034-5038

Franke WW, Schmid E, Winter S, Osborn M, Weber K (1979) Widespread occurrence of intermediate-sized filaments of the vimentin-type in cultured cells from diverse vertebrates. Exp Cell Res 123:25-46

Franke WW, Moll R, Schiller DL, Schmid E, Kartenbeck J, Müller H (1982) Desmoplakins of epithelial and myocardial desmosomes are immunologically and biochemically related. Differentiation 23:115-127

Franke WW, Kapprell HP, Cowin P (1987) Immunolocalization of plakoglobin in endothelial junctions: identification as a special type of zonulae adhaerentes. Biol Cell 59:205-218 
Franke WW, Goldschmidt MD, Zimbelmann R, Mueller HM, Schiller DL, Cowin P (1989) Molecular cloning and amino acid sequence of human plakoglobin, the common junctional plaque protein. Proc Natl Acad Sci USA 86:4027-4031

Franke WW, Borrmann CM, Grund C, Pieperhoff S (2006) The area composita of adhering junctions connecting heart muscle cells of vertebrates. I. Molecular definition in intercalated disks of cardiomyocytes by immunoelectron microscopy of desmosomal proteins. Eur J Cell Biol 85:69-82

Garrod DR, Merritt AJ, Nie Z (2002) Desmosomal cadherins. Curr Opin Cell Biol 14:537-545

Godsel LM, Getsios S, Huen AC, Green KJ (2004) The molecular composition and function of desmosomes. In: Behrens J, Nelson WJ (eds) Cell adhesion. Handbook of experimental pharmacology, vol 165. Springer, Berlin, pp 137-193

Goossens S, Janssens B, Bonne S, De Rycke R, Braet F, Hengel J van, Roy F van (2007) A unique and specific interaction between alphaT-catenin and plakophilin-2 in the area composita, the mixed-type junctional structure of cardiac intercalated discs. J Cell Sci 120:2126-2136

Gresser O, Weber E, Hellwig A, Riese S, Regnier-Vigouroux A (2001) Immunocompetent astrocytes and microglia display major differences in the processing of the invariant chain and in the expression of active cathepsin L and cathepsin S. Eur J Immunol 31:1813-1824

Grossmann KS, Grund C, Huelsken J, Behrend M, Erdmann B, Franke WW, Birchmeier W (2004) Requirement of plakophilin 2 for heart morphogenesis and cardiac junction formation. $\mathrm{J}$ Cell Biol 167:149-160

Gumbiner BM (1996) Cell adhesion: the molecular basis of tissue architecture and morphogenesis. Cell 84:345-357

Hamm S, Dehouck B, Kraus J, Wolburg-Buchholz K, Wolburg H, Risau W, Cecchelli R, Engelhardt B, Dehouck M-P (2004) Astrocyte mediated modulation of blood-brain barrier permeability does not correlate with a loss of tight junction proteins from the cellular contacts. Cell Tissue Res 315:157-166

Hämmerling B, Grund C, Boda-Heggemann J, Moll R, Franke WW (2006) The complexus adhaerens of mammalian lymphatic endothelia revisited: a junction even more complex than hitherto thought. Cell Tissue Res 324:55-67

Hatta K, Takeichi M (1986) Expression of N-cadherin adhesion molecules associated with early morphogenetic events in chick development. Nature 320:447-449

Hatzfeld M (2007) Plakophilins: multifunctional proteins or just regulators of desmosomal adhesion? Biochim Biophys Acta 1773:69-77

Hazan RB, Kang L, Roe S, Borgen PI, Rimm DL (1997) Vinculin is associated with the E-cadherin adhesion complex. J Biol Chem 272:32448-32453

Hazan RB, Phillips GR, Qiao RF, Norton L, Aaronson SA (2000) Exogenous expression of $\mathrm{N}$-cadherin in breast cancer cells induces cell migration, invasion, and metastasis. J Cell Biol 148: 779-790

Heid HW, Moll R, Schwetlick I, Rackwitz HR, Keenan TW (1998) Adipophilin is a specific marker of lipid accumulation in diverse cell types and diseases. Cell Tissue Res 294:309-321

Hendrix MJ, Seftor EA, Meltzer PS, Gardner LM, Hess AR, Kirschmann DA, Schatteman GC, Seftor RE (2001) Expression and functional significance of VE-cadherin in aggressive human melanoma cells: role in vasculogenic mimicry. Proc Natl Acad Sci USA 98:8018-8023

Hendrix MJ, Seftor EA, Hess AR, Seftor RE (2003) Vasculogenic mimicry and tumour-cell plasticity: lessons from melanoma. Nat Rev Cancer 3:411-421

Herrmann H, Fouquet B, Franke WW (1989) Expression of intermediate filament proteins during development of Xenopus laevis. I. cDNA clones encoding different forms of vimentin. Development 105:279-298

Hess AR, Seftor EA, Gardner LM, Carles-Kinch K, Schneider GB, Seftor RE, Kinch MS, Hendrix MJ (2001) Molecular regulation of tumor cell vasculogenic mimicry by tyrosine phosphorylation: role of epithelial cell kinase (Eck/EphA2). Cancer Res 61:3250 3255

Hess AR, Seftor EA, Gruman LM, Kinch MS, Seftor RE, Hendrix MJ (2006) VE-cadherin regulates EphA2 in aggressive melanoma cells through a novel signaling pathway: implications for vasculogenic mimicry. Cancer Biol Ther 5:228-233

Hofmann I, Schlechter T, Kuhn C, Hergt M, Franke WW (2008) Protein p0071, an armadillo plaque protein that characterizes a specific subtype of adherens junctions and their functions. J Cell Sci (in press)

Janzer RC, Raff MC (1987) Astrocytes induce blood-brain barrier properties in endothelial cells. Nature 325:253-257

Kleihues P, Cavenee WK (2000) Pathology and genetics of tumours of the nervous system. WHO classification of tumours. IARC Press, Lyon

Knapp AC, Franke WW (1989) Spontaneous losses of control of cytokeratin gene expression in transformed, non-epithelial human cells occurring at different levels of regulation. Cell 59: $67-79$

Knapp AC, Bosch FX, Hergt M, Kuhn C, Winter-Simanowski S, Schmid E, Regauer S, Bartek J, Franke WW (1989) Cytokeratins and cytokeratin filaments in subpopulations of cultured human and rodent cells of nonepithelial origin: modes and patterns of formation. Differentiation 42:81-102

Lampugnani MG, Dejana E (1997) Interendothelial junctions: structure, signalling and functional roles. Curr Opin Cell Biol 9:674-682

Lampugnani MG, Corada M, Caveda L, Breviario F, Ayalon O, Geiger B, Dejana E (1995) The molecular organization of endothelial cell to cell junctions: differential association of plakoglobin, beta-catenin, and alpha-catenin with vascular endothelial cadherin (VE-cadherin). J Cell Biol 129:203-217

Landis DM, Reese TS (1981) Membrane structure in mammalian astrocytes: a review of freeze-fracture studies on adult, developing, reactive and cultured astrocytes. J Exp Biol 95:35-48

Lane NJ (1981) Invertebrate neuroglia-junctional structure and development. J Exp Biol 95:7-33

Langbein L, Grund C, Kuhn C, Praetzel S, Kartenbeck J, Brandner JM, Moll I, Franke WW (2002) Tight junctions and compositionally related junctional structures in mammalian stratified epithelia and cell cultures derived therefrom. Eur J Cell Biol 81:419-435

Langbein L, Pape UF, Grund C, Kuhn C, Praetzel S, Moll I, Moll R, Franke WW (2003) Tight junction-related structures in the absence of a lumen: occludin, claudins and tight junction plaque proteins in densely packed cell formations of stratified epithelia and squamous cell carcinomas. Eur J Cell Biol 82:385-400

Lasek RJ, Tytell MA (1981) Macromolecular transfer from glia to the axon. J Exp Biol 95:153-165

Liebner S, Fischmann A, Rascher G, Duffner F, Grote E-H, Kalbacher $\mathrm{H}$, Wolburg H (2000) Claudin-1 and claudin-5 expression and tight junction morphology are altered in blood vessels of human glioblastoma multiforme. Acta Neuropathol 1000:323-331

Luo Y, Radice GL (2005) N-cadherin acts upstream of VE-cadherin in controlling vascular morphogenesis. J Cell Biol 169:29-34

Maher EA, Furnari FB, Bachoo RM, Rowitch DH, Louis DN, Cavenee WK, DePinho RA (2001) Malignant glioma: genetics and biology of a grave matter. Genes Dev 15:1311-1333

Maniotis AJ, Folberg R, Hess A, Seftor EA, Gardner LMG, Pe'er J, Trent JM, Meltzer PS, Hendrix MJC (1999) Vascular channel formation by human melanoma cells in vivo and in vitro: vasculogenic mimicry. Am J Pathol 155:739-752

Mertens C, Kuhn C, Franke WW (1996) Plakophilins 2a and 2b: constitutive proteins of dual location in the karyoplasm and the desmosomal plaque. J Cell Biol 135:1009-1025 
Mertens C, Kuhn C, Moll R, Schwetlick I, Franke WW (1999) Desmosomal plakophilin 2 as a differentiation marker in normal and malignant tissues. Differentiation 64:277-290

Miebach S, Grau S, Hummel V, Rieckmann P, Tonn J-C, Goldbrunner RH (2006) Isolation and culture of microvascular endothelial cells from gliomas of different WHO grades. J Neurooncol 76:39-48

Miettinen PJ, Ebner R, Lopez AR, Derynck R (1994) TGF-beta induced transdifferentiation of mammary epithelial cells to mesenchymal cells: involvement of type I receptors. J Cell Biol 127:2021-2036

Miyaki M, Tanaka K, Kikuchi-Yanoshita R, Muraoka M, Konishi M, Takeichi M (1995) Increased cell-substratum adhesion, and decreased gelatinase secretion and cell growth, induced by Ecadherin transfection of human colon carcinoma cells. Oncogene 11:2547-2552

Moll R, Sievers E, Hämmerling B, Schmidt A, Barth M, Kuhn C, Grund C, Hofmann I, Franke WW (2008) Endothelial and virgultar cell formations in the mammalian lymph node sinus: Endothelial differentiation morphotypes characterized by a special kind of junction (complexus adhaerens). Cell Tissue Res (in press)

Nagafuchi A, Takeichi M (1989) Transmembrane control of cadherinmediated cell adhesion: a $94 \mathrm{kDa}$ protein functionally associated with a specific region of the cytoplasmic domain of E-cadherin. Cell Regul 1:37-44

Navarro P, Ruco L, Dejana E (1998) Differential localization of VEand N-cadherins in human endothelial cells: VE-cadherin competes with $\mathrm{N}$-cadherin for junctional localization. J Cell Biol 140:1475-1484

Nico B, Frigeri A, Nicchia GP, Corsi P, Ribatti D, Quondamatteo F, Herken R, Girolamo F, Marzullo A, Svelto M, Roncali L (2003) Severe alterations of endothelial and glial cells in the blood-brain barrier of dystrophic mdx mice. Glia 42:235-251

Osborn M, Ludwig-Festl M, Weber K, Bignami A, Dahl D, Bayreuther K (1981) Expression of glial and vimentin type intermediate filaments in cultures derived from human glial material. Differentiation 19:161-167

Oxford EM, Musa H, Maass K, Coombs W, Taffet SM, Delmar M (2007) Connexin43 remodeling caused by inhibition of plakophilin-2 expression in cardiac cells. Circ Res 101:703-711

Ozawa M, Kemler R (1990) Molecular organization of the uvomorulin-catenin complex. J Cell Biol 116:989-996

Paetau A, Mellström K, Westermark B, Dahl D, Haltia M, Vaheri A (1980) Mutually exclusive expression of fibronectin and glial fibrillary acidic protein in cultured brain cells. Exp Cell Res 129:337-344

Paffenholz R, Franke WW (1997) Identification and localization of a neurally expressed member of the plakoglobin/armadillo multigene family. Differentiation 61:293-304

Paffenholz R, Kuhn C, Grund C, Stehr S, Franke WW (1999) The arm-repeat protein NPRAP (neurojungin) is a constituent of the plaques of the outer limiting zone in the retina, defining a novel type of adhering junction. Exp Cell Res 250:452-464

Peifer M, Wieschaus E (1990) The segment polarity gene armadillo encodes a functionally modular protein that is the Drosophila homolog of human plakoglobin. Cell 63:1167-1176

Peifer M, McCrea PD, Green KJ, Wieschaus E, Gumbiner BM (1992) The vertebrate adhesive junction proteins beta-catenin and plakoglobin and the Drosophila segment polarity gene armadillo form a multigene family with similar properties. J Cell Biol 118:681-691

Peitsch WK, Grund C, Kuhn C, Schnoelzer M, Spring H, Schmelz M, Franke WW (1999) Drebrin is a widespread actin-associating protein enriched at junctional plaques, defining a specific microfilament anchorage system in polar epithelial cells. Eur J Cell Biol 78:767-778

Perez TD, Nelson WJ (2004) Cadherin adhesion: mechanisms and molecular interactions. In: Behrens J, Nelson WJ (eds) Cell adhesion. Handbook of experimental pharmacology, vol 165. Springer, Berlin, pp 3-21

Plate KH, Risau W (1995) Angiogenesis in malignant gliomas. Glia 15:339-347

Pontén J, Macintyre EH (1968) Long term culture of normal and neoplastic human glia. Acta Pathol Microbiol Scand 74:465-486

Pontén J, Westermark B (1978) Properties of human malignant glioma cells in vitro. Med Biol 56:184-193

Redies C (2000) Cadherins in the central nervous system. Progr Neurobiol 61:611-648

Rickelt S, Franke WW, Doerflinger Y, Goerdt S, Brandner JM, Peitsch WK (2008) Subtypes of melanocytes and melanoma cells distinguished by their intercellular contacts: heterotypic adherens junctions, adhesive associations and dispersed desmoglein 2 glycoproteins. Cell Tissue Res (in press)

Ridder LI de, Laerum OD, Mork SJ, Bigner DD (1987) Invasiveness of human glioma cell lines in vitro: relation to tumorigenicity in athymic mice. Acta Neuropathol 72:207-213

Risau W, Hallmann R, Albrecht U, Henke-Fahle S (1986) Brain induces the expression of an early cell surface marker for bloodbrain barrier specific endothelium. EMBO J 5:3179-3183

Roots BI (1981) Comparative studies on glial markers. J Exp Biol 95:167-180

Ryan JW, Ryan US, Habliston D, Martin L, Howell DS (1978) Synthesis of prostaglandins by pulmonary endothelial cells. Trans Assoc Am Physicians 91:343-350

Salomon D, Ayalon O, Patel-King R, Hynes RO, Geiger B (1992) Extrajunctional distribution of $\mathrm{N}$-cadherin in cultured human endothelial cells. J Cell Sci 102:7-17

Schmitt CJ, Franke WW, Goerdt S, Falkowska-Hansen B, Rickelt S, Peitsch WK (2007) Homo- and heterotypic cell-cell contacts in malignant melanoma cells and desmoglein 2 as a novel solitary surface glycoprotein. J Invest Dermatol 127:2191-2206

Schwarz MA, Owaribe K, Kartenbeck J, Franke WW (1990) Desmosomes and hemidesmosomes: constitutive molecular components. Annu Rev Cell Biol 6:461-491

Seftor EA, Meltzer PS, Schatteman GC, Gruman LM, Hess AR, Kirschmann DA, Seftor RE, Hendrix MJ (2002) Expression of multiple molecular phenotypes by aggressive melanoma tumor cells: role in vasculogenic mimicry. Crit Rev Oncol Hematol 44:17-27

Somjen GG (1981) Neuroglia and spinal fluids. J Exp Biol 95:129-133

Staehelin LA (1974) Structure and function of intercellular junctions. Int Rev Cytol 39:191-283

Stein GH (1979) T98G: an anchorage-independent human tumor cell line that exhibits stationary phase G1 arrest in vitro. J Cell Physiol 99:43-54

Steinberg MS (1996) Adhesion in development: an historical overview. Dev Biol 180:377-388

Steinberg MS, McNutt PM (1999) Cadherins and their connections: adhesion junctions have broader functions. Curr Opin Cell Biol 11:554-560

Steinberg MS, Takeichi M (1994) Experimental specification of cell sorting, tissue spreading, and specific spatial patterning by quantitative differences in cadherin expression. Proc Natl Acad Sci USA 91:206-209

Stewart PA, Wiley MJ (1981) Developing nervous tissue induces formation of blood-brain barrier characteristics in invading endothelial cells: a study using quail-chick transplantation chimeras. Dev Biol 84:183-192

Straub BK, Boda J, Kuhn C, Schnoelzer M, Korf U, Kempf T, Spring H, Hatzfeld M, Franke WW (2003) A novel cell-cell junction system: the cortex adhaerens mosaic of lens fiber cells. J Cell Sci 116:4985-4995

Straub BK, Stoeffel P, Heid H, Zimbelmann R, Schirmacher P (2008) Differential pattern of lipid droplet-associated proteins and de 
novo perilipin expression in hepatocyte steatogenesis. Hepatology 47:1936-1946

Strumane K, Berx G, Roy F van (2004) Cadherins in cancer. In: Behrens J, Nelson WJ (eds) Cell adhesion. Handbook of experimental pharmacology, vol 165. Springer, Berlin, pp 69-103

Takano T, Tian G-F, Peng W, Lou N, Libionka W, Han X, Nedergaard M (2006) Astrocyte-mediated control of cerebral blood flow. Nat Neurosci 9:260-267

Takeichi M (1977) Functional correlation between cell adhesive properties and some cell surface proteins. J Cell Biol 75:464-474

Takeichi M (1990) Cadherins: a molecular family important in selective cell-cell adhesion. Annu Rev Biochem 59:237-252

Takeichi M (1995) Morphogenetic roles of classic cadherins. Curr Opin Cell Biol 7:619-627
Treherne JE (1981) Glial-neurone interactions. J Exp Biol 95:1-240

Vestweber D, Kemler R (1985) Identification of a putative cell adhesion domain of uvomorulin. EMBO J 4:3393-3398

Wheelock MJ, Johnson KR (2003) Cadherins as modulators of cellular phenotype. Annu Rev Cell Dev Biol 19:207-235

Wolburg H, Neuhaus J, Kniesel U, Krauß B, Schmid E-M, Öcalan M, Farrell C, Risau W (1994) Modulation of tight junction structure in blood-brain barrier endothelial cells. J Cell Sci 107:1347-1357

Wuchter P, Boda-Heggemann J, Straub BK, Grund C, Kuhn C, Krause U, Seckinger A, Peitsch WK, Ho AD, Franke WW (2007) Processus adhaerentes: giant cell processes studded with special adherens junctions attract and connect mesenchymal stem cells. Cell Tissue Res 328:499-514 